\title{
Historical and archaeological analysis of the Church of the Nativity
}

\author{
Michele Bacci ${ }^{\mathrm{a}}$, Giovanna Bianchi ${ }^{\mathrm{b}, *}$, Stefano Campana ${ }^{\mathrm{b}}$, Giuseppe Fichera ${ }^{\mathrm{b}}$ \\ a Department of historical sciences, university of Fribourg, Switzerland \\ ${ }^{\mathrm{b}}$ Department of historical sciences and heritage, University of Siena, Italy
}

\section{A R T I C L E I N F O}

\section{Article history:}

Received 9 October 2012

Accepted 9 October 2012

Available online 22 November 2012

\section{Keywords:}

Nativity church

Bethlehem

Historical analysis

History of archaeological excavations

Archaeological analysis of architecture

History of architecture

\begin{abstract}
A B S T R A C T
The team has considered the special status of the Basilica of Bethlehem, which is not just a monument of outstanding historic and artistic importance, but also and fundamentally a holy place, that has long been and is still perceived as a memorial site, marking the place of Christ's birth and transcribing into a sacred topography the main events of the Gospel narratives. Because of such a peculiarity, the team considered that it was indispensable to analyze the Basilica of Bethlehem from different viewpoints, namely those of archaeological and historical research. The historical approach aims at understanding the centuries-old development of the holy site as a ritual space and the materialized expression of holiness, the ways in which it has been perceived and used, and the messages that it was meant to convey to its beholders. It combines the findings of previous archaeological research with the data provided by the analysis of written evidence, including old textual sources about the Basilica (especially chronicles and pilgrims'accounts). For the archaeological study of the Basilica of the Nativity, we used the methodology of its investigation of the Archeology of Architecture. Stratigraphical analysis was carried out in relation to various portions of the church walls, as well as in relation to the buildings that make up the whole complex, in order to understand the dynamics of major changes in the structure in its entirety. Direct analysis of evidence from the walls was supported by the reading of existing literature and historical maps with particular reference to the plans of the church.

These tools of investigation have been applied to the analysis of the church in its entirety, including its underground cavities.
\end{abstract}

c) 2012 Published by Elsevier Masson SAS.

\section{Research aims}

The historical research was devoted to the examination of the previous archaeological, historical, and art-historical secondary literature on the Bethlehem basilica and to a sampling of old written sources, by focusing on the history of the basilica and on its transformations down the centuries, which can be usefully combined with the data provided by archaeological and architectural analysis.

The main aim of the archeological research consists in the application of the stratigraphical method to architecture. The analysis of the plan of the building, which was in the past the most debated topic, has been integrated with the observations of the stratigraphical relationships that we made, analysing the external standing walls of the basilica.

The present study is part of a wide-ranging project commissioned, and funded, by the Palestinian National Authority. The project, awarded after an international tender, was aimed at the

\footnotetext{
* Corresponding author. via Roma 56, 53100 Siena, Italy. Tel.: +3905 77233636.

E-mail address: giovanna.bianchi@unisi.it (G. Bianchi).
}

analysis of the historical and archeological aspects, at assessing the physical and structural decay of the Church in all its components (see [1] and [2]) and at the analyses of the mosaics [3].

\section{Historical analyses - M.Bacci}

\subsection{Bethlehem as historical problem}

In the context of the international team for the survey, assessment study, and conservation plan for the Basilica of the Nativity, the unit being responsible for historical and archaeological analysis has been focused on the historical aspects and the gathering of written sources. The research work was developed on two different, yet strictly intertwined, grounds:

- it aimed at providing the other units with historical information being useful for the current works of investigation of the roofs and other material parts of the buildings;

- it provided some grounds for a thorough reassessment of the historical problems underlying the site and its architecturalartistic peculiarities, starting from an analysis of the different 
methodological approaches applied by past scholars to the interpretation of the Nativity church.

In first instance, it must be remarked that, despite the large number of publications concerning the site, many aspects of its history still prove to be disregarded or uninvestigated. More specifically, the contributions of experts in many different disciplinary fields have mostly not been merged into a general history of the Basilica. The scholarly debate started already in the 16th and 17th centuries with the publications by both Greek and Franciscan authors who basically dealt with the origins of the site, its holy mementoes in their devotional and commemorative significance, and the properties and rights granted to each Christian community. From the 19th century onwards, the basilica has been investigated from the viewpoint of historical-religious topography [4,5], architectural history [6-8], structural analysis [9,10] and archaeology [11-13], and art history and iconography [14-19]. Whereas the early history of the building has been much discussed since the very beginnings, its developments in the Byzantine and Crusader periods have been more specifically investigated only in much more recent works. Notwithstanding the large amount of written sources bearing witness to the history of the monument in the later centuries, the latter have not so much retained the attention of scholars.

\subsection{State of the field}

To some extent, the abundance and variety of sources constitute a limitation to the development of historical research. Chronicles and archival documents occasionally shed some lights on specific aspects of the site history. Yet, pilgrims' accounts constitute by and large the most important category of written sources: those worked out from the 4th through the late 13th century are easily accessible in a published collections of texts in both their original language (Greek, Latin, Armenian, and Arabic) and Latin, Greek, English or French translations [20-26]. On the other hand, from the 14th century onwards pilgrimage reports and descriptions of the holy sites were disseminated almost everywhere and were written in almost all the European and Mediterranean languages (including Italian, Spanish, Portuguese, French, English, German, Danish, Czech, Polish, Hungarian, Croatian, Serbian, Bulgarian, Russian, Greek, Armenian, Georgian, Arabic, Persian, and Ethiopic); a thorough examination of all such sources [27] proves to be extremely difficult, as many of them have published by scholars interested only in their historical-linguistic aspects and, even if some of them can be accessed through some anthologies of texts [23,24,28-36] have never been gathered within systematic databases, a preliminary attempt being that recently established by the project Digiberichte of Kiel University (www.digiberichte.de).

Iconographic sources include views of the city and the basilica, plans, illustrated proskynetaria, and elevations of the building. Mostly dating from the late 16th century onwards (including the important engravings by Natale Bonifacio, Bernardino Amico, Cornelis van Bruyn, Roberts and Bartlett), they have been already published and used by most of the scholars dealing with the history of the Nativity church [13]; yet a thorough catalogue of all extant witness is still lacking. Another important source of information is represented by the Palestinian wooden and mother-of-pearl model reproductions of the Basilica, many of which were the object of a specific investigation by Michele Piccirillo [37].

Archaeological investigations were occasionally executed in the 19th century in the Franciscan compound. New and more accurate excavations and soundings were made in 1932 in the narthex, in 1033-1934 in several parts of the basilica [38], and again in 1947 through 1951 in the area of the Franciscan convent [13]. Soundings of the remnants of mosaic in the nave and transept took place in 1983 under the auspices of the Deutsches Archäologisches Institut and the Görres-Institut and were carried on by Prof. Gustav Kühnel, whose work still remains partly unpublished $[17,39]$.

On the whole, the contributions given by many different scholars have managed to shed light on specific aspects of the history of the Basilica, yet a wider and fuller interpretation of the site is still lacking and many questions remain unanswered. In some respects, past scholars have sometimes proved to disregard the true peculiarity of the Nativity church, which is by itself not just a very eminent historical site and a very sumptuous manifestation of monumental architecture, but also and very specifically a "mnemotopos", i.e. a topographical transcription of several events mentioned in the Christian Holy Scriptures and religious tradition [40]. This specificity distinguishes the Palestinian loca sancta from any other holy place in the Christian world: inasmuch as they are perceived to bear witness to Christ's Incarnation and to be imbued with a holy power connected to their contact with Christ's body, they are also deemed to be holy and deserving veneration; the ways in which holy events have been more or less firmly associated with specific sites and public devotion to them has been architecturally, spatially, and visually promoted to the eyes of pilgrims and devotees constitutes a specific field of research which remains largely uninvestigated.

\subsection{Major themes of Bethlehem's architectural and artistic history}

The location of Christ's birth and its deposition in the manger on the cave of Bethlehem, on the second hill over the Wadi el-Charubeh, was already hinted at in the writings of Justin Martyr (mid-2nd century) and Origenes (3rd century) and was clearly promulgated by the writings of ecclesiastical writers from the 4th century onwards, as well as by the descriptions of a number of early pilgrims. According to the view especially defended by Franciscan authors $[41,42]$ but recently rejected by Taylor [43], the memory of the location had possibly been preserved by the local JewishChristian communities.

The sumptuous church erected by Constantine, according to Eusebius of Caesarea's account, was actually not the main focus of the pilgrim's experience, as it was basically conceived of as a beautiful and monumental frame marking the site of and giving access to the underground cave, where visitors were allowed to worship the visual and spatial mementoes of Jesus' birth. The special setting of the cave itself, including, among others, the gilded revetment of the manger and later on the visualization of the connected event by means of a mosaic image, was just one of the many strategies worked out since the very beginnings in order to enhance and stimulate the visitor's feeling of holiness associated to the site. In the course of time the nearby grottoes and some specific spots in the basilica itself and its surroundings were alternatively identified with either minor events of the Nativity story (e.g., the site where the Magi left their horses, the place of Christ's circumcision, the tombs of the holy innocents, the place where a drop of the Virgin's milk had fallen down, the site of Christ's firth bath, the palm under which, according to Islamic tradition, the Virgin Mary gave birth to Jesus, etc.) or the documented presence of important personages of church history near the basilica (Jerome, John of Damascus, etc.). Such locations may vary according to the different views of each Christian community, the multifarious perceptions and experiences of visitors, and the different emphasis laid on each event in the course of time.

As visual and tangible evocations of holy history, holy spots and their setting played a primary role in the pilgrim's experience of the Bethlehem basilica. Yet, if compared to other Palestinian holy sites, the latter's aesthetic appeal and monumental appearance was often recorded as something unexpected; especially from 
the 14th century onwards, many visitors stated that the building was by far the most striking and beautiful of the whole Holy Land. According to Eusebius, it had been constructed by Emperor Constantine to enshrine the site of Christ's birth at the same time as the Holy Sepulcher (marking the site of His death and burial) and the Eleona church on the Mount of Olives (celebrating the spot of His ascension to Heaven). Since the 17th century, the Constantinian origins of the present-day basilica have been frequently a matter of debate. Early sources witness that a basilica was erected on the site shortly after the Council of Nicaea in 325 and that the latter was already built up by 333, when it was mentioned by the anonymous pilgrim from Bordeaux; such witness had been traditionally used, especially by Latin authors [44], to corroborate the idea by which the whole building dated back to the early 4th century, whereas Greek writers [45] had laid more emphasis on the role played by Emperor Justinian in the mid-6th century, notwithstanding the lack of any hint at Bethlehem in Procopius' book On Buildings, which records the Byzantine ruler's many and multifarious acts of patronage; actually the rebuilding of the church by order of Justinian after the damages caused by a revolt of the Samaritans is first clearly witnessed in the 10th century Arabic chronicle by Patriarch Eutychius of Alexandria.

The excavations made in the 1930s through the 1950s first shed light on the early architectural history of the basilica, by revealing that the eastern end was at a certain time transformed from an octagonal structure into a triconch, and by discovering remnants of a 4 th or early 5 th century mosaic pavement in some areas of the present-day bema and main nave. Many scholars have subsequently accepted the view expressed by Vincent and Abel $[5,46]$ according to which the remaking of the east end should date from the Justinianic era, whereas the nave should be regarded as the original 4th-century building. Others have preferred to regard the building as stylistically uniform and to think of either a Justinianic [47] or an earlier date, sometimes in the late 5 th or early 6 th century [48-50]. The date of such ornamental features as capitals or the foliate motifs on the architraves in the nave has been also much debated and there is no agreement as whether they were actually made in Constantine's times or are to be interpreted as later interpretations of Constantinian formulae $[51,52]$. The two bronze doors of the Nativity Chapel are almost universally considered to date from the age of Justinian $[53,54]$.

A dating of the triconch in the Crusader period has been recently formulated by the American scholar Jordan Pickett during a symposium in Jerusalem in November 2010 (Visual Constructs of Jerusalem); this proposal implies that the east end was at a certain point destroyed, notwithstanding the curious silence of old sources about the fate of the building in the long period between the Empire of Justinian and the Latin conquest of Palestine in 1099. A legend known from a 9th century Byzantine source emphasizes that the basilica had not been destroyed during the Persian invasion of 614, whereas Islamic writers from the 10th and 11th centuries clearly state that, during the Arab conquest of 636, the Caliph Omar had extended his protection over the church of the Nativity. According to some authors, a mihrab was built up in the southern apse and the palm mentioned in the Holy Quran, under which Mary had given birth to Jesus, was preserved in its interior; Islamic pilgrims paid their respects to the place, which was apparently not even damaged during the destructions operated by the Egyptian Caliph al-Hakim in 1009 [55].

Such evidence seems to indicate that, at the arrival of the Crusaders in 1099, the Basilica was in fairly good conditions. The enhanced status of the city, the use of the building as coronation church for Balduin I in the year 1100, the elevation of Bethlehem to a bishopric in 1108 , and the intensification of pilgrimage in the subsequent decades stimulated its embellishment with new furnishings and ornaments. First of all, it was provided with liturgical structures enabling the performance of the Latin rite, as well as utensils and precious vasa sacra, including the organ, bells, candlesticks and brass bowls with scenes from the life of Saint Thomas unearthed in 1869 and now in the Museum of the Flagellation Convent in Jerusalem. Sometimes in the two decades preceding Sultan Salah ad-Din's reconquest of Palestine in 1187, the Nativity grotto was refurbished by sculptors from the Temple area workshop, who revested its outer walls with white marble, enclosed the Justinianic entrances within arched doorways and transported there the 6 th century bronze doors originally included in the metal chancel delimiting the altar area of the early Christian basilica. Visitors soon started manifesting their piety by occasioning the painting of some columns in the south nave with images of saints and figures of supplicants: on the first one in the second raw Saint Jacob the Great is accompanied by a bowing male figure, exhibiting a shell fixed onto his mantle that so declares his status as a pilgrim to Santiago de Compostela; closer is an image of the Virgin Glykophilousa being worshipped by a group of both male and female supplicants, whose prayer is expressed by a Latin inscription bearing the date 1130 . The rows of columns looking onto the central nave are decorated with images, which seem to pertain to a somewhat later, and more uniform, campaign of mural decoration.

By the far the most extensive program of decoration made in the Crusader period is represented by the mosaics, which embellish the upper portions of the walls in the nave and transept. Although only remnants are preserved today, old descriptions [56] witness that they originally decorated the whole building with representations of the Virgin Mary in the apse conch and a sequence of Evangelic events in the transept, whereas the genealogy of Christ, the provincial councils of Syria-Palestine, and monumental figures of angels where displayed in the main nave and the Tree of Jesse in the western wall. A double Latin and Greek inscription in the apse recorded that the decoration had been the outcome of a joint sponsorship by the Byzantine Emperor Manuel Comnenus, the King of Jerusalem Amaury (Amalricus) and the Latin bishop of Bethlehem Raoul in the year 1169. Such a collaboration between Latin and Greek rulers acting as donors for the same monumental context proves to be unparalleled in the history of Medieval art and witnesses that the universally shared interest in the holy places could also give birth to extraordinary phenomena of cross-cultural and trans-confessional patronage. The same inscriptions reveal the name of the painter Ephraim, possibly a Greek or Melkite Syrian who conceived the whole program of decoration according to the stylistic and compositional patterns being widespread in the Comnenian period of Byzantine history. Another inscription, written in both Latin and Syriac and included in the lower margin of one of the archangels, reveals the name of one "Basilius the Deacon", who was most likely a local Palestinian artist working under the direction of Ephraim. The presence of Palestinian workmanship may explain such distinctively local devices as the use of mother-of-pearl for the rendering of round-shaped ornaments within the mosaics; moreover, the strong connection of the whole cycle with the figural arts of the Holy Land is evidenced by the imitation of some ornamental patterns included in the mosaic decoration of the Dome of the Rock in the Haram es-Sharif in Jerusalem.

The involvement of the Armenian community in the decoration of the church is best revealed by the magnificent wooden door in the narthex, which is sculpted with high-relief crosses (khatchkars) and includes an Arabic and an Armenian inscription mentioning the Sultan of Damascus al-Malik al-Mu'azzam (1218-1227) and the King of Cilicia Hethum I (1226-1270), as well as Father Abraham and Father Arakel, who made the work in the year 1226 [57,58]. 


\subsection{New evidence on past restorations}

The history of the basilica after the Crusaders is still scarcely investigated, the main study being still that by Vincent and Abel [5]. It can be said, in general terms, in the 13th through the 19th century the building did not undergo significant alterations: according to both Ayyubid, Mamluk and Ottoman customary law, Christians were allowed to preserve their churches but they were prevented from both erecting new buildings and embellishing old ones; in order to make repairs, it was necessary to receive a special permission from the Sultan himself. Because of lack of maintenance the church started falling into a state of decay, as was frequently remarked, from the 14 th century onwards, by those same pilgrims who never stopped manifesting their astonishment for the beauty of the church, its paintings, marble incrustations, monumental columns, and magnificent roof. The sumptuous marble revetments of the side walls had been frequently stolen, as was witnessed by both the visitors' accounts and the late medieval legend reporting that a huge snake had miraculously appeared when a Sultan had attempted at removing some precious slabs: some pilgrims stated that the clear signs of its body could be clearly remarked on their surface. As stated by the Greek pilgrim Arsenios in 1512, the latter, as well as other remnants of the marble revetments, were preserved only in the bema and the choir, whereas the nave had been completely deprived of them [59]. By the second half of the 15th century, portions of the mosaic decoration had started falling down, as was remarked by Louis de Rochechouart in 1461 [60] and Felix Fabri in 1480 [61].

Nonetheless, the most serious problems concerned the church roof. The medieval one, which was always described as made with several qualities of wood (cedar of Lebanon and cypress) and covered with lead, was by the late 15 th century in such a bad state of preservation, that rain fell down from its many holes and the pavement was covered with birds' dung, even if, according to some sources, a first restoration had been accomplished in 1435 under the auspices of the Greek Emperor of Trebizond Alexios Komnenos Doukas [62]. Yet, the portion of roof overhanging the choir was going to collapse when the Italian pilgrim visited the church in 1474 and saw that the Franciscan friars had been obliged to erect a wooden structure to hold it up [63]. As we are informed by Friar Francesco Suriano [64], the Franciscan Guardian Giovanni Tomacelli obtained the Sultan's permission for the thorough restoration of the roof; this fact is also witnessed by the original firman [65] and Felix Fabri's account [61]. Tomacelli was an Observant friar and his efforts to restore the basilica's ancient decorum manifested a radical change of attitude, implicitly contrasting that of the previous Conventual administration (as is implied by Suriano's words). He was able enough to obtain sponsorships from the Duke of Bourgogne and the King of England; whereas the latter's money was used for the lead covering, the former's was invested for the making of the new wooden structure. Venetian carpenters and wood-carvers came to Bethlehem to take measurements and they subsequently made beams out of pine-woods from the Alps. The materials were then transported by ship to Jaffa and thence transferred to Bethlehem by means of camels and oxen; special machines were constructed in order to transport the hugest and longest beams.

Sources are silent about the roof in the 16th century, but as early as 1607 and later on in 1617 its condition had become precarious, and the Greek community was allowed to operate some substitutions of rotten beams. Yet, a much more efficacious intervention took place on the initiative of the Greek Patriarch Dositheos in 1672: thanks to the sponsorship of a rich Greek devotee, Manolakis of Kastoria, it was possible not only to renovate the roof with new beams from Mytilene and a new lead covering, but also to make new ornaments in the church. The windows, which had been previously closed with hard stones, were substituted with iron casings and glass; some of the nave walls were plastered, and the entrances to the Nativity grotto were embellished with new marble slabs $[45,62]$.

Only interventions for the building's ordinary maintenance took place in the 18th century, except for the restoration, in 1775, of a wall, located close to the west entrance, that was going to collapse [62]. In 1834, the basilica was damaged by an earthquake and already by 1837 the Greek community had received lots of offerings from the devotees to make new embellishments in the narthex [66]. Finally, in 1842 the Sultan Abdul Mecit, answering to the official request of the Greek Patriarch Athanasius III, gave permission to work out a thorough renovation of the wooden roof and its lead coverings; on the same occasion, a new pavement was made in the choir with marble slabs from the Propontis and in the nave with local stones [62]. At the same time, with the exception of the extant remnants of the 12th century mosaic decoration, the upper portions of the nave and transept walls where almost completely covered with a thick plastering; according to some authors [5], significant portions of mosaic may have be hidden under this plastering and it would prove extremely important to bring them back to visibility, with the help of a thermographic analysis and a thorough restoration of the walls.

That of 1842 was the last significant intervention made in the basilica, whereas the furnishings and setting of the Nativity grotto and the other neighboring caves were strongly altered in the late 19th and early 20th centuries. By 1912, according to J.M. de Vogüé [6], the mosaics had become much darker than they were in the mid-19th century.

\section{Archaeological excavations at the Church of the Nativity- S. Campana}

There have been relatively few archaeological excavations in or around the Basilica, all having taken place since the last part of the XIX century. The first known investigations occurred in 1871 with the accidental discovery of the Grotto del Lavacro against the eastern apse on the northern side of the Basilica. From this work, undertaken by a friar of the Fransciscan Community in the course of research inspired by a number of ancient texts, there remain some meagre records in the archives of the Custodia di Terra Santa, along with a later synthesis published by Bagatti in his 1952 book Gli Antichi Edifici Sacri di Bethlemme. The excavation, within the giardino dei limoni, revealed a short flight of steps beneath a vaulted opening, the five steps of which led down to an underground space a few metres in diameter within the floor of which was a small pool. On the basis of the surviving records and of his own observations Bagatti suggested that the grotto had been deliberately constructed in this way as part of the rebuilding of the Basilica during the work carried out by Justinian, perhaps in recognition of some kind of veneration already attributed to it during the Constantinian period [13].

The next excavations, undertaken in 1932 during the British Mandate for Palestine, concentrated on the atrium to the west of the church. The results were published by R.W. Hamilton, the director of the excavations, in the Quarterly of the Department of Antiquities in Palestine [12]. Vincent [67] and Richmond [68], in the years immediately following the excavations, presented their own interpretations. There are some inconsistencies between the various accounts but the excavations made it possible to document a westerly extension of the north and south walls of the atrium. In this regard there is a reference reported only by Bagatti [13]- without support from any other publication, archival source or other record - concerning excavations in 1906 carried out during repairs to the gates of the Greek cemetery. During this work there was 
uncovered a wall which flanked the north side of the atrium along the same line as the north wall of the Basilica.

Turning to the extended walls of the atrium that came to light in the 1932 excavations the various authors are in agreement about their similarity to the present-day walls of the Basilica. The walls were described clearly by Hamilton as being constructed of regular courses of squared masonry marked by the use of a comb-pick. The extended walls marked out an area $64.20 \mathrm{~m}$ long by $28.20 \mathrm{~m}$ wide, subdivided by a cross-wall. Vincent described the cross-wall as being of smaller dimensions and made of residual material. Hamilton, by contrast, maintains that it shared the same dimensions and construction technique as the perimeter walls, making it comparable to those of the Basilica. The atrium would thus have had two distinct parts, one facing onto the Basilica and the other looking west towards the village, to which it was connected by a paved street. In the eastern part of the atrium there was found a further cross-wall, now represented by the stylobate within the atrium of the Basilica. Apart from the archaeological evidence this view is supported by iconographic sources and by the hypothetical reconstructions put forward by Amico (1609) and Vogüé [6].

These first substantive excavations were considered by scholars as an extraordinary opportunity to resolve a key historical problem which at that time still remained unresolved: the attribution of the present-day building either to Constantian or alternatively to Justinian. In practice it was not possible from the documentary sources to resolve this conundrum with any certainty, the description by Sophronius in 602 AD of the building as tripleapsed deriving from too late a date to demonstrate whether the form observed by him belonged to Justinian (527-565 AD) or to the work of the earlier emperor. At a later date Eutychius, during the $\mathrm{X}$ century, maintained that Justinian had the church demolished as being too small, so as to reconstruct it in the form of a grander and more handsome structure. This source, however, is considered unreliable as potentially relying more on mythology than demonstrated fact; moreover, the Corinthian columns of the church have been considered by most archaeologists to date from the fourth century $[5,67]$. In contrast to this view there is that of Viollet-le-Duc who maintained that the whole of the building should be attributed to Justinian [11]. As far as the dating of the church was concerned another question that still remained unresolved lay in the attribution of the structure either to a single period of construction or to two or more identifiable phases. The thesis that the building derived from a single chronological period was advanced in a multi-authored volume edited by Lethaby and Harvey and published in 1910. Subsequently, there was no lack of opposing hypotheses, for example that of Vincent and Abel based on observation of the roof of the northern grotto where there was visible the foundation of the northern perimeter wall, continuing across part of the northern apse. From this and other considerations (for instance, the connecting walls between the apses having the same dimensions as the external walls of the main body of the church) they suggested that Justinian limited himself to the addition of the three semi-circular apses to the original Constantinian structure.

In 1934 further excavations, beginning with little more than trial trenches, were undertaken within the Basilica itself, resulting in a series of publications by Harvey [69], Richmond [68], Vincent [67], Crowfoot (1941), and Hamilton [12]. In this case, the genesis of the excavations, as in the earlier episodes, lay in the need to carry out restoration work. The investigations were aimed at defining the structural maintenance work necessary in response to the earthquake of 1927. In particular, Harvey, commissioned by the Palestinian government to carry out a structural analysis of the Basilica, records that in the first instance excavation work was not envisaged but that this became necessary following the identification of possible cavities beneath parts of the floor [70]. The first trench was opened at the eastern end the southern aisles but in itself did not resolve the problem. The most important result was the uncovering at a depth of ca. $75 \mathrm{~cm}$ below the present floor of a mosaic pavement. This prompted more extensive excavations in other parts of the church, which brought to light an important cycle of mosaic representations extending throughout a large part of the nave and into parts of the aisles.

Furthermore, the excavations in the north-eastern sector of the church uncovered significant elements of the plan of the Constantinian church, revealing an octagonal structure with a sunken circular 'well' located immediately above the Grotto of the Nativity, conjectured by Harvey to have a its real entrance from the west although no architectural evidence exists to show how, in the earlier church, access was provided to the grotto. The excavations also showed that the columns of the nave rested upon a stylobate, which extended without a break along the length of the nave, cutting the previously-existing mosaics and itself resting directly upon the native rock. In the great levelling of the ground surface to facilitate construction of the church in the Justinian period there were found numerous fragments of roof tiles which Harvey attributed to the covering of the Constantinian structure, along with pottery of the VI century that confirmed the Justinian reconstruction.

The new data broadly confirmed the reading of Vincent [5] who had long maintained that the layout and structure of the present-day church was for the most part attributable to Justinian, as opposed to Weigand's insistence on the Constantinian character of the basilica [51]. On the basis of the discoveries made during the excavations of 1932 and 1934, Richmond [68], Vincent [67] and Hamilton [12] put forward hypothetical reconstructions of the principal phases in the life of the church, as illustrated here in Figs. 1-2.

These observations and suggestions are fundamental to further discussion but it is worth emphasising that they are based on a small number of relatively limited excavations, leaving many questions unresolved. For example, it is not possible to determine whether the flanking walls and stylobate in the atrium belonged to the Constantinian period, nor whether the building of the first church coincided with or preceded the laying of the mosaic pavement. The internal disposition of structural features within the Constantinian basilica still remained unknown, with the octagon at the east either containing an oculus into the underlying Grotto or alternatively providing support for an altar. More generally, are we really looking at a complete octagonal structure or alternatively at the eastern part of an octagonal apse? Bagatti's book of 1952 maintains for example that on the basis of the evidence available at that time the octagon could in reality have belonged to an polygonal apse and that the supposed oculus might alternatively have provided the base of the ciborio over an altar situated directly above the Grotto-a reading which, if confirmed, would reconcile a series of elements that are out of keeping with known traditions within the Christian church (Fig. 3).

Kühnel [71] and Pringle [8], on the other hand, were inclined towards an alternative view of the Constantinian church. They proposed that this would have consisted of a colonnaded atrium and a longitudinal body with a central nave and four flanking aisles, one bay shorter on the west than the present church. This in turn would have been connected at the east to an octagonal structure with surrounding ambulatory, with flights of descending steps so as to provide pilgrims with a view into the sacred Grotto of the Nativity immediately below. The combination of a basilica with a central feature of this kind, occurring here for the first time, was in Kühnel view an innovation that was entirely in keeping with the ideas of the imperial architects, while the technique of construction - involving the use of shaped masonry blocks rather than the typical brickwork of the Roman period - could be interpreted as a response to local building traditions within Palestine. Then, 

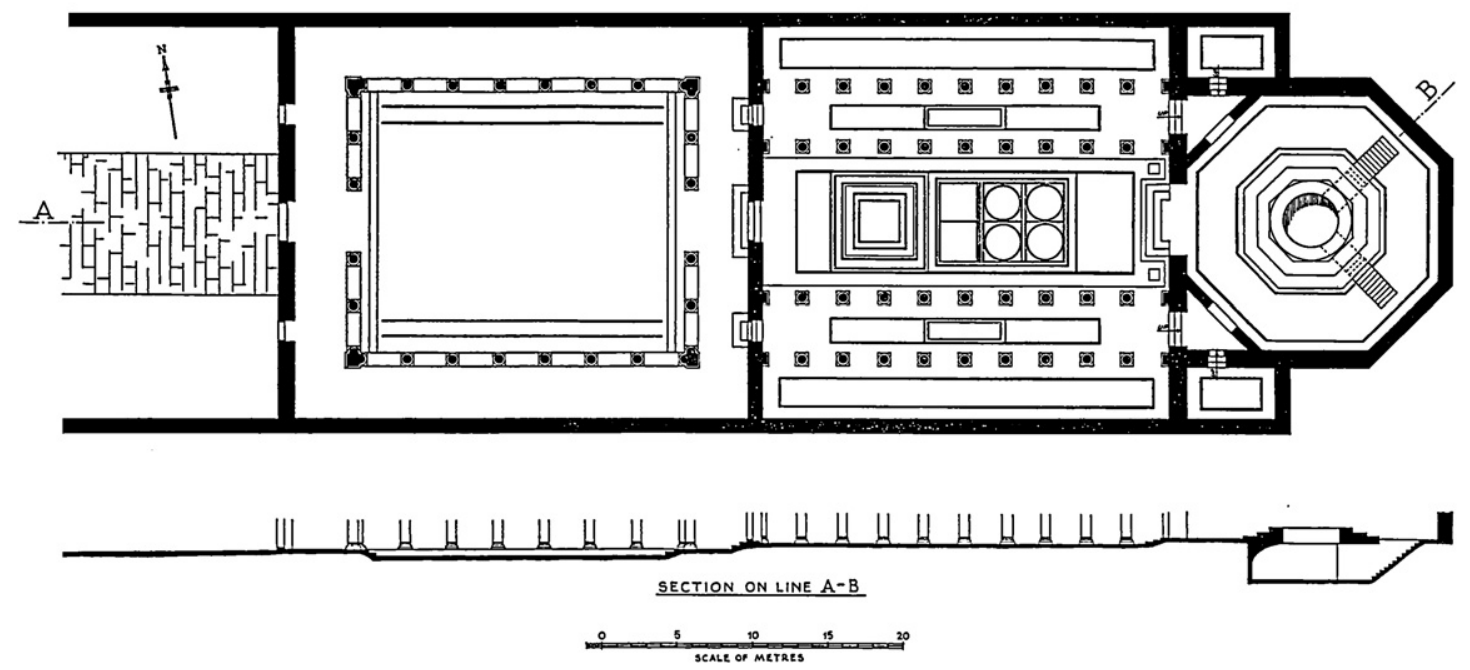

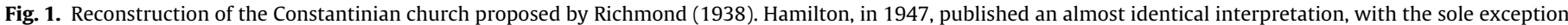
of the omission of the steps within the octagon.

as now, only renewed stratigraphical excavations could hope to resolve some of these outstanding questions.

The excavations of 1948 and 1949, undertaken in connection with the restoration of the medieval cloister and published in 1952 by Bagatti, consisted of three trenches in the northwestern corner of the Justinian narthex and in the medieval cloister itself; other excavations were undertaken by the Custodia di Terra Santa of the Latin cemetery to the north of the convent. Bagatti's 1952 volume presents a thoroughgoing review of the literary, iconographic and archaeological evidence, offering a comprehensive analysis of the Basilica and of the surrounding buildings. The new excavations made it possible to clarify certain situations, in particular in the
Justinian narthex containing the northeastern pilastro of the Constantinian atrium. Over and above the revised interpretation of the Basilica and of the adjacent structures, the most interesting contribution, however, comes from Bagatti's attention to the elevations and in particular to the structural elements of the western facade and the bell tower of the XII century $[8,13]$.

The work on the alterations to the western facade must be seen as the most important after the reconstruction of the church in the VI century. On the basis of present knowledge we can assume that when the crusades arrived at Bethlehem at the end of the XI century they found the church substantially as it appeared in the VI century. The same does not hold true, however, for the monastic

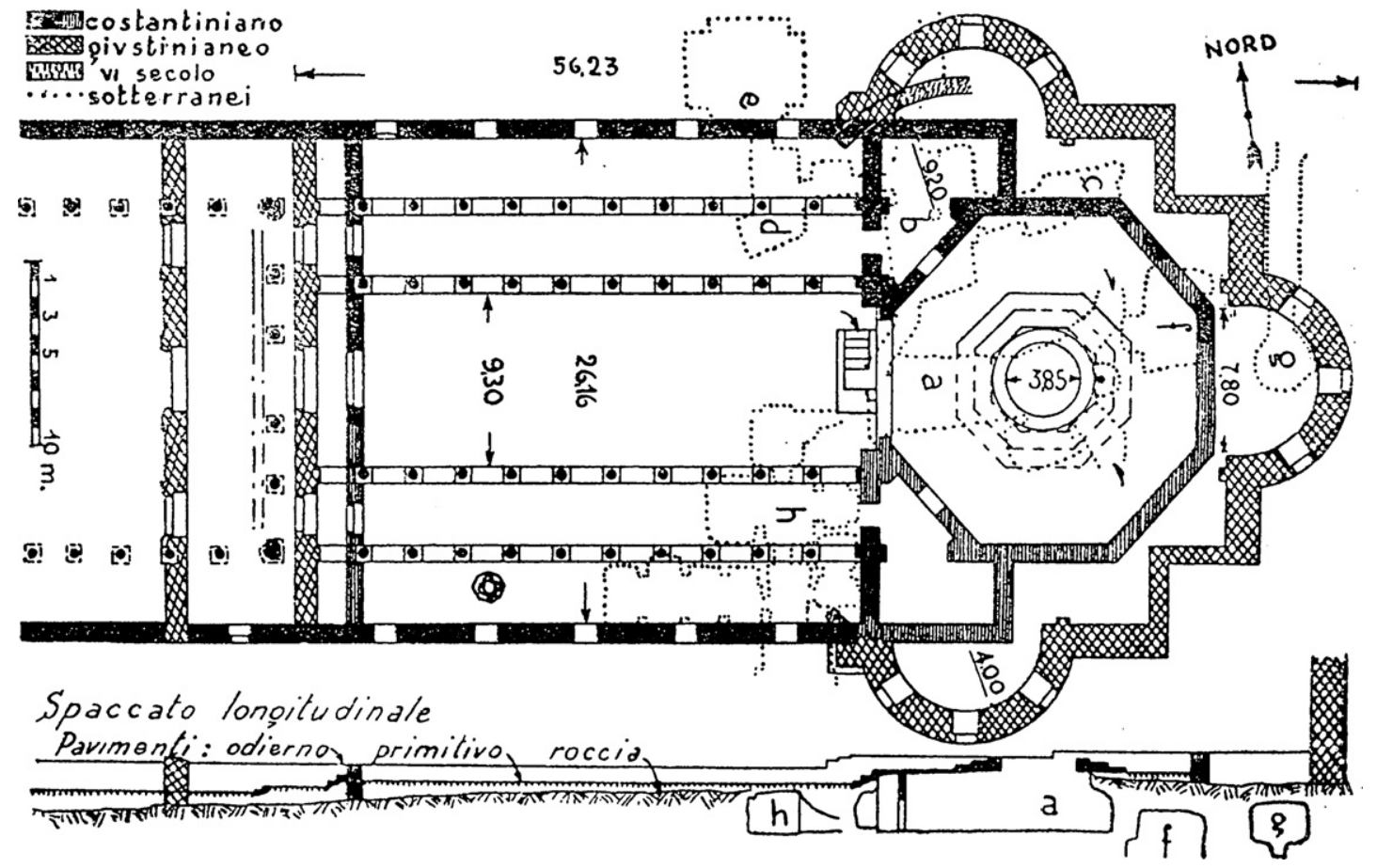

Fig. 2. Overall plan of the Basilica according to the reconstruction of Bagatti (1952). 


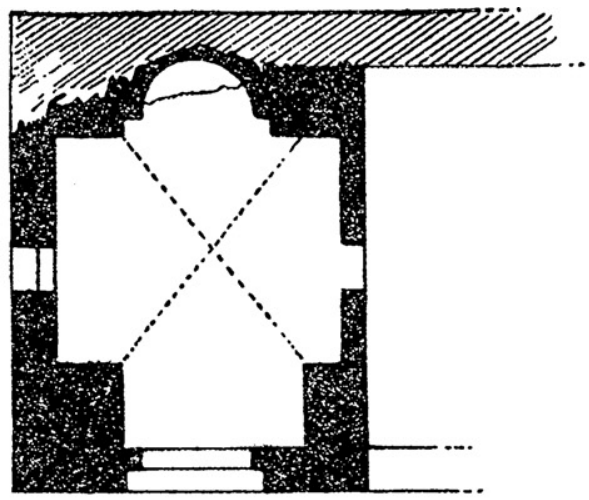

pianta a quota (8.90)
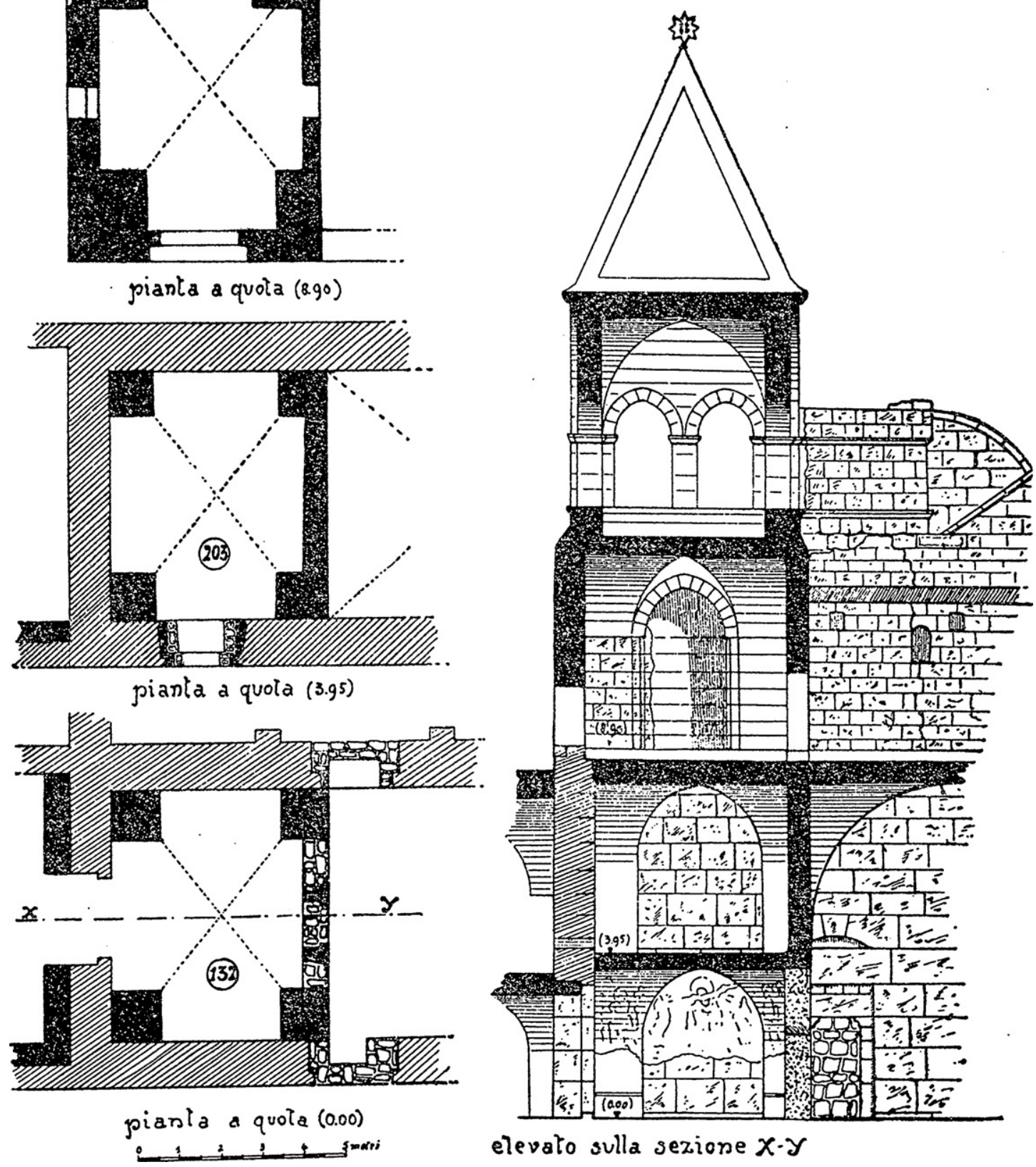

Fig. 3. Plans, sections and reconstruction of the medieval bell tower proposed by Balduzzi.

Bagatti, 1952.

structures that grew up alongside the Basilica. The alterations to the facade took place during the XII century and involved the closure of two of the entrances into the narthex and the modification of the central entrance through the insertion of a narrower doorway with a pointed arch $[8,38]$. The bell-tower is located on the north side of the facade. It measured about $6 \mathrm{~m}$ by $8 \mathrm{~m}$ at its base and was inserted into the northwestern part of the VI-century narthex, extending this upwards by a further three storeys. Three bells were found in 1863 in the medieval cloister and another 13 in 1906 outside the cloister a little further to the north. According to Elart the bells should be attributed to the XIII century [7,8]. The most significant interventions in the Basilica, apart from the addition of the bell-towers and the modification of the entrance[s], are those in the interior and in particular the redecoration of the ancient building through the introduction of cycles of representations and the paintings on the columns which constitute the most imposing cycle in the ambit of monumental painting within the Terra Santa [71].

\section{Archeological analysis of the architecture}

4.1. The method of archeological analysis of architecture - G. Bianchi

Despite the fact that the prime objective of the project was restoring the roof of the basilica, the close connection between the monument's walls and its roof has led to an overall study of the 


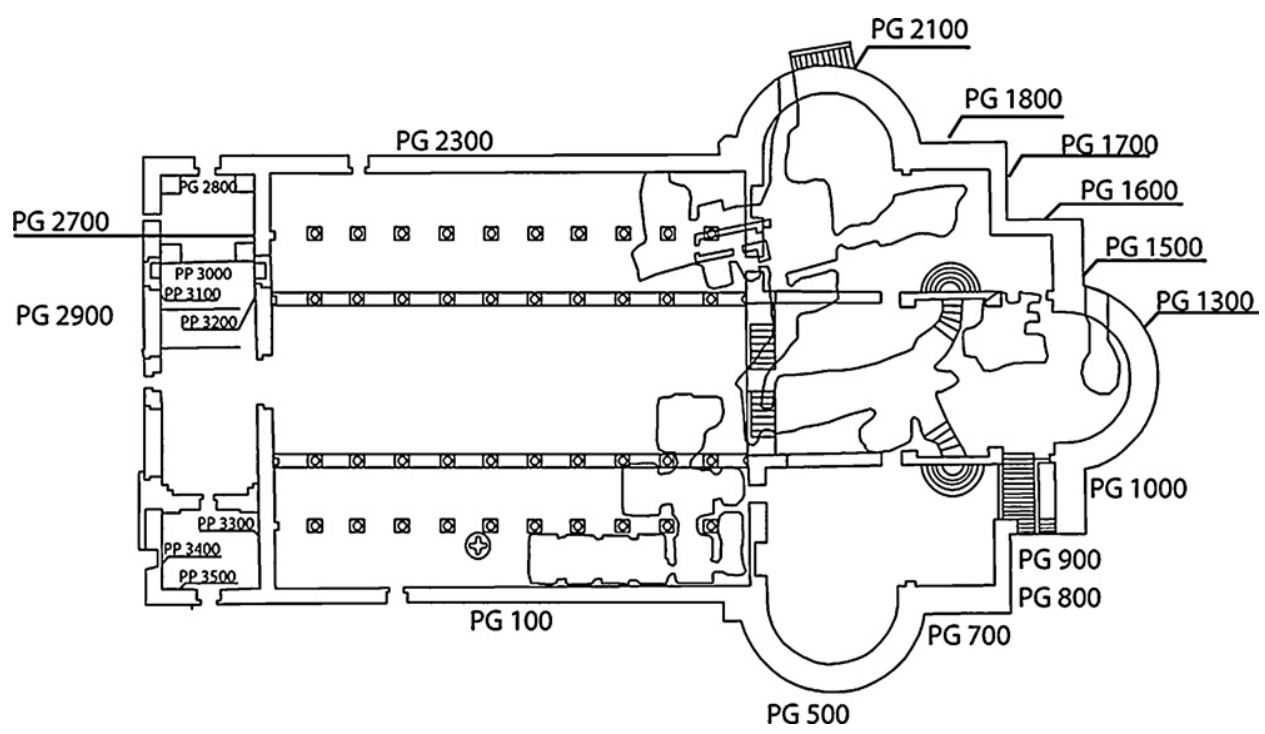

Fig. 4. Plan of Basilica (ground floor).

material features, backed up by the methodological tools of the Archeology of Architecture.

Within this discipline, which was developed in the context of Italian Medieval Archeology, starting in the 1970s, methodological tools have been developed which have borrowed the principles of stratigraphical sequencing from traditional archeology, with the aim of identifying, in the fabric of walls, the traces and relationships of the main actions involving construction and destruction which have taken place over time. This allows us to identify the different phases of life of the building itself, thanks to the identification of the physical and stratigraphical relationships between the various transformations in the construction of the architecture. At the same time, the analysis of the features of the fabric of the wall, such as construction techniques, types of windows, and the formal decisions made regarding the plan of the building and its original formulation, allow one to reconstruct the stages involved in the production cycle connected to the world of building, the level of specialization of the builders and craftsmen involved, and the financial resources of the people who paid for the work.
The stratigraphical analysis of the architecture has made it possible to shed light on the construction sequences of the monumental complex, thanks to objective criteria that have been tried and tested in other research contexts, but so far never applied to the Church of the Nativity. In the most important studies carried out in the past, preference has instead been given to a kind of investigation based above all on analyzing documentary sources, and on criteria of analysis borrowed from art history or the history of architecture, where the history of architecture is referred to in the sense of an overall view of the changes in the plan, and in the entire architectural volumes. The only material evidence that has always been referred to in the various studies relates to the findings from excavations inside the building (see the contribution from Campana, below). Only Bagatti, in his monographical work, paid attention to specific characteristics of parts of the walled structures, with special attention to the building techniques used [13]. Bagatti's work also includes further, interesting considerations regarding the construction sequence and the physical relationships between the walls of the basilica that the author was unable to explore, since the

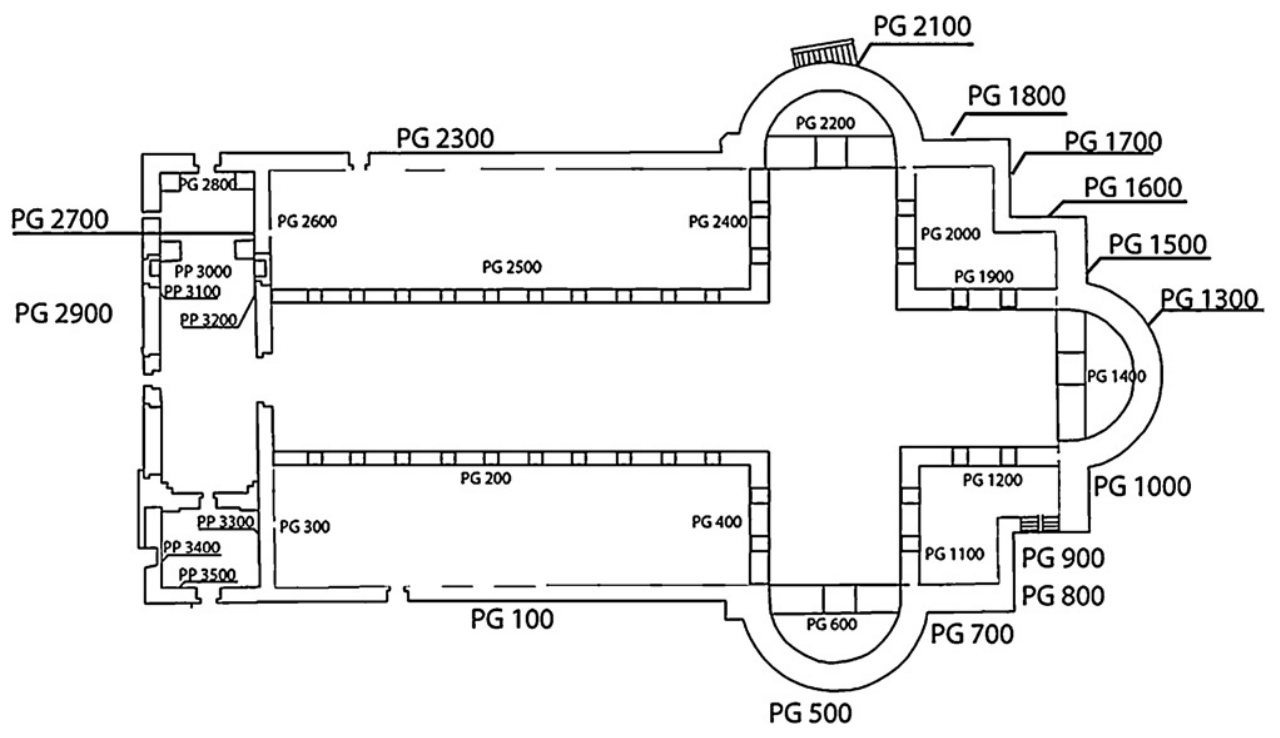

Fig. 5. Plan of Basilica (roof level). 


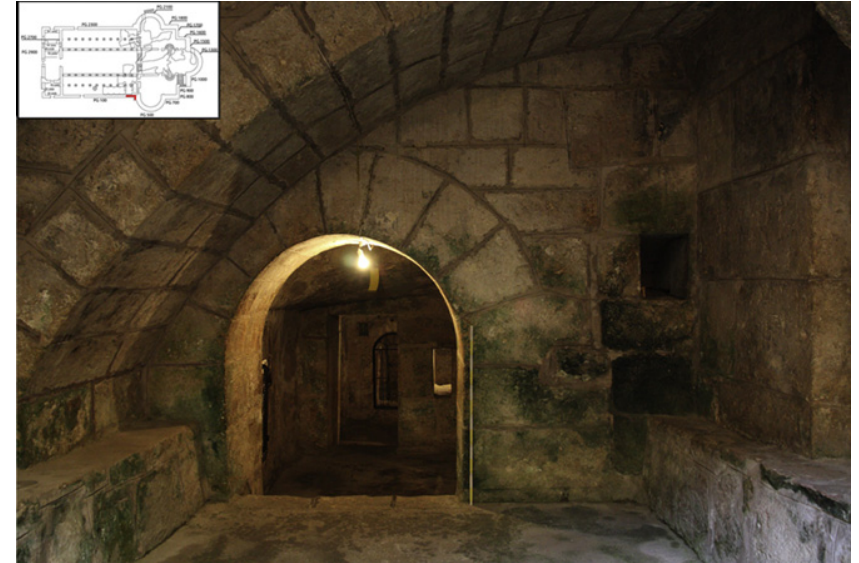

Fig. 6. Arched entrance to caves located on south side of aisle.

analytical tools of the Archeology of Architecture were not available at that time.

\subsection{Analysis of the architecture - G. Fichera}

The interpretive approach adopted in the course of this research related to the building in its entirety, and is divided into three "levels", corresponding to: the basement level of the caves and grottoes, whose construction has been placed in relation to the rest of the walls of the complex; the ground floor level of the basilica; and finally the level corresponding to the higher parts visible from the terraces and the original walkways. The illustration of the findings will go back over the main stages in the study, and will be subdivided into a description of the four sides of the basilica, canonically laid out along an east-west axis, and the subject of an overall analysis aimed at verifying the stratigraphical relationships involving the main events of construction and destruction, and describing the characteristics of the building technique (Figs. 4 and 5).

The internal elevations of the basilica itself were omitted from the overall analysis, given that the various types of facing (plaster, mosaic, and wall linings) did not make it possible to conduct a complete analysis of the sequence in which the walls were built.

\subsubsection{The system of caves}

The underground level of the basilica has a complex system of rock-cut chambers. The most important of these is certainly the Grotto of the Nativity, which is located in the exact centre of the current presbytery area, and which in the Justinian era had two new access points on the northern and southern sides. The archeological analysis carried out, cross-referring data from the building's plan and technological data (stratigraphical relationships, construction technique, working tools...), has made it possible to place the construction of the caves in relation to the chronology of the basilica above, and thereby to put forward new suggestions for interpretation, in the panorama of studies of the monument.

On the south side, close to the garden which is currently maintained by the Greek Orthodox Church, the steps begin that lead to a system of cavities which in ancient times bore the name "Caves of the Innocents", although the original entrance to them was probably a set of steps carved directly into the rock, which are still partially preserved below the modern-day steps.

The entrance to the underground corridor is crowned by a round arch located exactly vertically below the nave wall above, and stratigraphically linked to a perpendicular wall corresponding to the wall which, at ground level, connects the nave to the apse (Fig. 6). Analysis of the construction technique, the tool marks on the stone, and the kind of round arches of the internal walls in the corridor of the caves, aligned north-south, shows that these were built at the same time as the rest of the structure.

The observation of the survey of the floor-plan, carried out by Denys Pringle [8], has also shown that the size of the caves gradually diminishes as one moves toward the internal parts (Fig. 4). The first underground chamber corresponds to the space of five bays in the nave, the second chamber to the space of three bays, and the last one to a single bay. On the basis of the survey, and the recording of the material evidence, it is seen that in the grotto chamber the rocky mass supporting the nave columns above has been left in place. This is a further clue confirming the fact that the grottoes were created at the same time as the system of walls and columns belonging to the basilica above. In the remaining grottoes, no such details have been found, and for this reason the material evidence points to the fact they may have predated the construction of the basilica we see today.

A second, smaller grotto is situated exactly below the central apse, and is called the "Grotto of the Bathing". The entrance to the grotto, which does not communicate with the ones next to it, is today made possible via a corridor created at the end of the 19th century [13], since the original access, being at the level of the outer ground level, must have been direct. The walls defining the access to the grotto very probably show an intention to give the cave a monumental scale. They also show considerable building skill in creating the double archway, the first being situated vertically below the external apse elevation, and the second practically in the centre of the thickness of the wall, and inclined in line with the curve of the apse. The space between the two is covered by a vault composed of long squared blocks high above the system of steps leading down to the level of the grotto. These walls stand directly on rock, more or less at the level of the original ceiling of the grotto. In the centre of the grotto, the walls of which are lined with a layer of plaster, a basin has been dug into the ground. This is $0.73 \times 0.76 \mathrm{~m}$ in size, with a depth of $0.84 \mathrm{~m}$. Its side walls are lined with plaster. The basin, fed by a system of terracotta pipes arriving from the north, one small part of which is still visible in the western wall of the access steps, was also surrounded by a floor paved with stone slabs, although only a few remains of this are preserved (Fig. 7). The technical characteristics, and the stratigraphical relationships, make it possible to attribute this construction to the era of the basilica above, while it is not possible to determine with certainty how long before the grotto was excavated, and with what function.

The "Grotto of the Nativity", situated in the centre of the current basilica, and in the centre of the previous Constantine-era church [13], has a rectangular shape which has an east-west alignment, with a niche on the southern side, where the altar of the manger stands. From an archeological point of view, the presence of marble slabs, pictures and paintings, almost completely lining the walls up to the ceiling, makes it impossible to put forward further hypotheses.

The steps leading down to the system of grottoes located on the northern side of the basilica, known as the "Caves of St Jerome", were created below the northern apse, and thus inside the modernday Church of St Catherine. In this instance, the underground chambers have a more complex plan than the caves seen so far, with a subdivision into numerous internal chambers. While the evidence from the wall of the access doorway attests to a contemporaneous relationship with the work carried out in the construction of the basilica we see today, it is harder to try to establish when the caves were dug, by stylistic analogy both with the arch above the door and in terms of the construction technique. This is true especially owing to the high number of renovation interventions and attempts to integrate the walls inside the grotto, which prevent one from suggesting possible associations. However, the fact that at least two of the columns of the nave above seem to stand above an empty space 

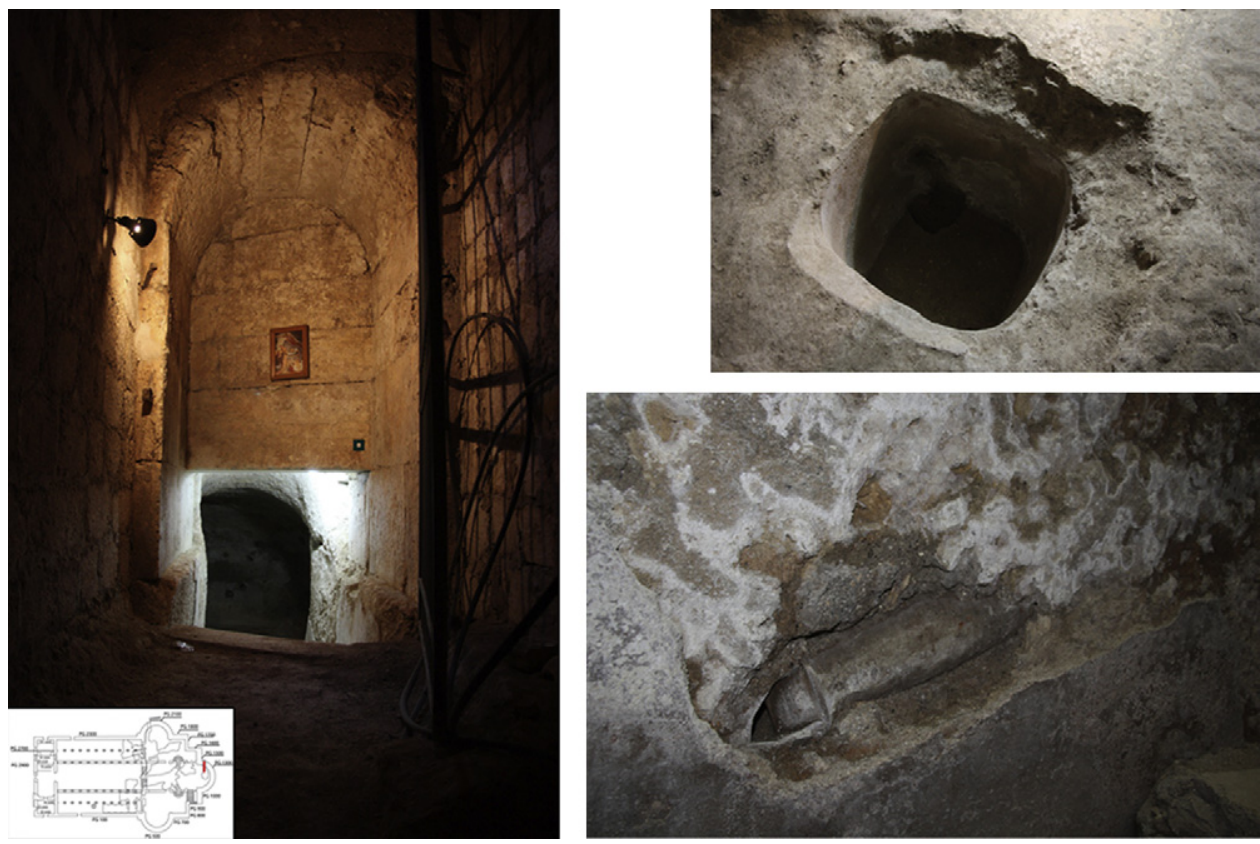

Fig. 7. Entrance to cave located in eastern apse, and detail of basin dug in center of chamber. Lower down: detail showing clay tubing still present in walls of cave.

makes it possible to suggest that this grotto, just like the Grotto of the Nativity, may predate the construction of the modern basilica.

\subsubsection{The elevations}

4.2.2.1. Southern facade. The southern facade of the basilica, now subdivided between the area under the Armenian community on the south-western side, and the Greek Orthodox community on the south-eastern side, is preserved almost intact, and the only portion which remains impossible to investigate is that relating to the south-western corner of the narthex, covered by buildings constructed in the Crusader era. Moreover, slightly further to the east, a wall that stratigraphically rests against the wall elevation separates the Armenian part from the Greek Orthodox part.

The elevation can be broken up into three levels, the lowest of which is currently visible inside the "Gottoes of the Innocents", described above. The middle section constitutes the wall of the side nave situated at the same level as the courtyard (Elevation 100), and the top portion represents the continuation of the wall of the central nave (Elevation 200).

The wall located at the level of the courtyard has a series of four windows, now blocked up by irregularly-shaped stones, with an abundant use of mortar (Fig. 8). The fact that the windows are contemporary with the wall itself is proven by the fact that the window openings are topped by an architrave comprising a single stone that occupies exactly the space of two courses of stone-work, and by the fact that the architrave is stratigraphically associated with the fabric of the wall. However, the sides of the windows, corresponding to the window jambs, have irregular edges, as if an attempt had been made to widen them. A fifth window is situated near the church's facade, in the garden belonging to the Armenian community. This has been blocked up with a thick layer of mortar, on the surface of which a sharp instrument has been used to reproduce the horizontal and vertical lines of the adjacent wall elevation. Finally, in the western margin of the elevation, the stratigraphical relationships reveal a lower section of wall, made of large stone blocks bonding the body of the narthex to that of the nave, and an upper part in which the volume of the narthex rests on the body of the church. This would reveal a very clear dynamic of construction, whereby the construction of the lower part of the wall came first, followed by the completion of the nave, and finally the narthex, at least on the southern side of the basilica.

Continuing upwards, a careful analysis of the elevation above the level of the gutter has revealed an intervention to raise the level of the wall of the nave, very probably in the Crusader period. This intervention is evidenced by a gradual reduction of the size of the stone masonry blocks, by a change in the way they were worked, and in the way they were finished, and by the inclusion of pieces that were probably reused in the external elevation, as for example a long block of pink limestone with a line, and other inscribed marks. Furthermore, a decorative device also visible on the northern side of the basilica, consisting in a series of blocks which the builders deliberately left protruding in the side of the transept wall, was in this case in part removed and partly used to bond with the upper extension of the wall, which probably served to fortify and defend this side of the building (Fig. 9).

Above this elevation, there is the top portion of the wall of the central nave (Elevation 200), in which there are 11 round-arch windows (Fig. 10). The easternmost of these windows, located in the

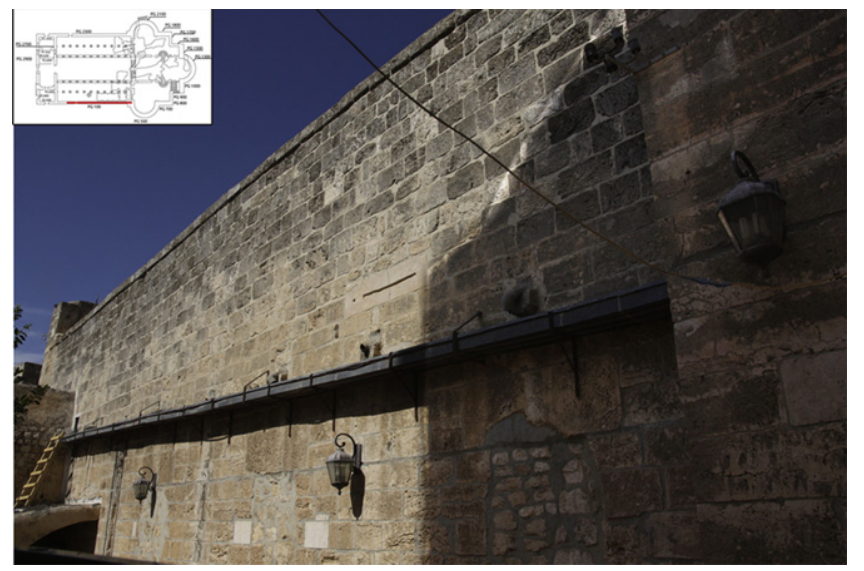

Fig. 8. Exterior wall of south aisle, with blocked up windows. 


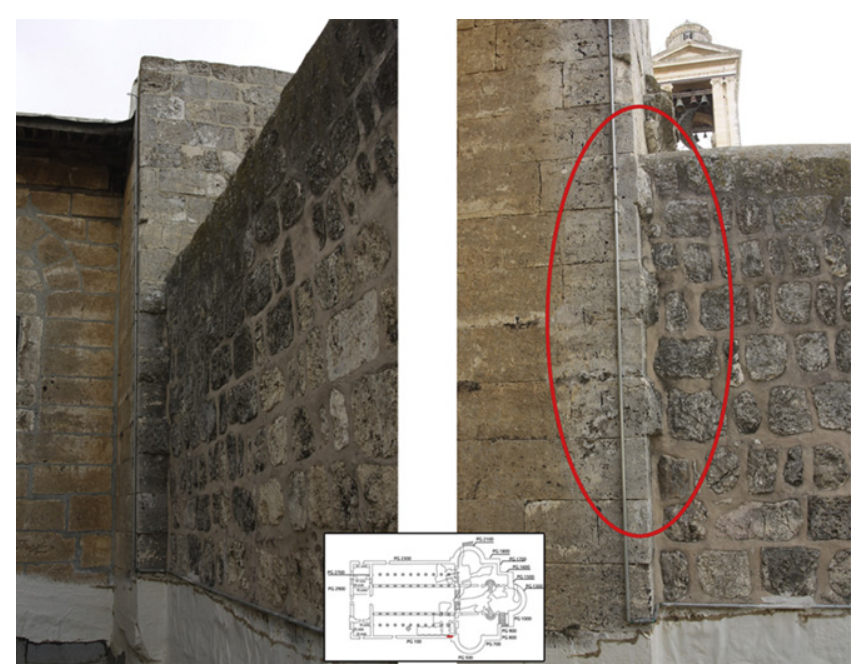

Fig. 9. Bonding system of raised section of south wall of aisle.

point where the wall bonds with the transept, is currently blocked up, and has some of the wedge-shaped stone elements of the arch missing. This is the only example of parts removed from any of the numerous windows of the basilica. According to Bagatti, the windows were blocked up in 1560 [13].

At the point of contact between the wall of the nave and the transept wall, one can see a technical expedient which shows, with extreme clarity, the considerable skill of the builders, and the fact that the two perimeter walls were built at the same time. This is a semi-pilaster composed of stone blocks with four visible faces. This was difficult to build, but extremely effective in "bonding" the two wall structures together.

The western wall of the southern transept (Elevation 400) constitutes the wall that connects the perimeter wall of the nave and the south apse. It is marked by the presence of two round-arch windows, both blocked up, similar to the adjacent window in the nave wall (Fig. 11). Starting from the sill of the southern window, one notes a line of discontinuity in the way the wall is devised, which includes within it the right-hand side of the window, too. On the opposite side of the church, in an extremely symmetrical position, it is possible to see the same dividing line. This is solely an indication of a specific method of construction, and not, as other writers have suggested several times in the past, of different construction phases. The two dividing lines indicate a specific

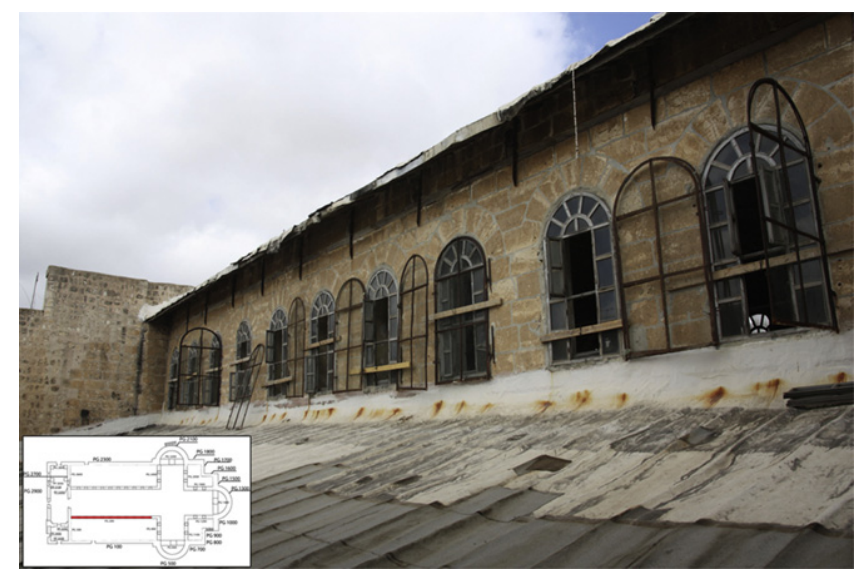

Fig. 10. Elevation 200. Top part of south wall of nave.

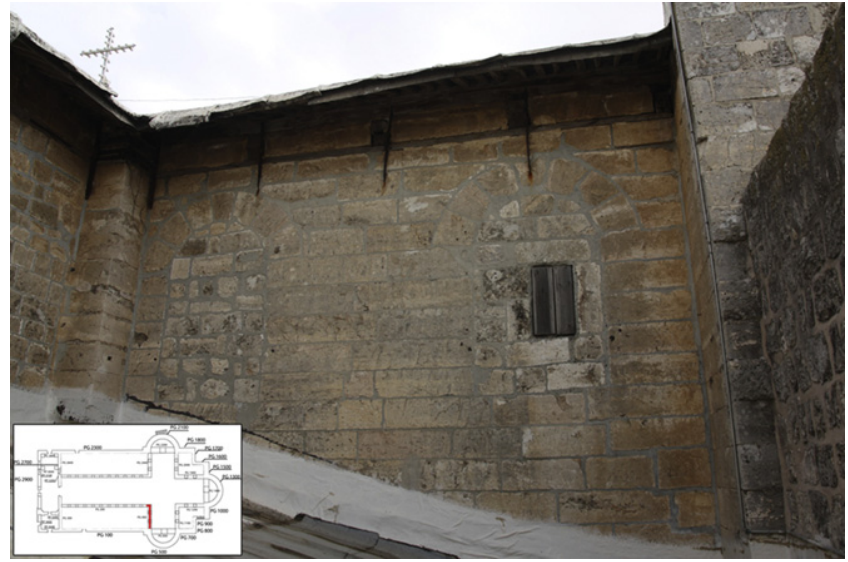

Fig. 11. Elevation 400 . Western wall of south transept.

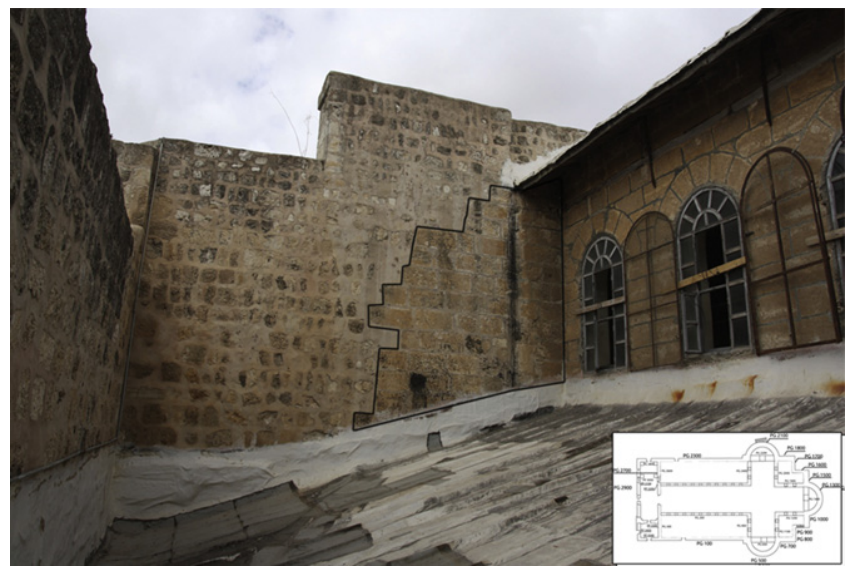

Fig. 12. Elevation 300. South wall of counter-facade. The line shows the surviving original portion.

stratigraphical relationship, on the basis of which the bloc comprising the three apses rests against the bloc comprising the basilica's nave, within a building project which displays a strong unity of design, and total contemporary status in the chronology of these building parts. Accordingly, construction would have started from the western side, before proceeding subsequently to the construction of the apses, which were joined together with the body of the nave at a point corresponding to the aforementioned breaks in the line of the build. Thus, starting from the level of the window-ledges

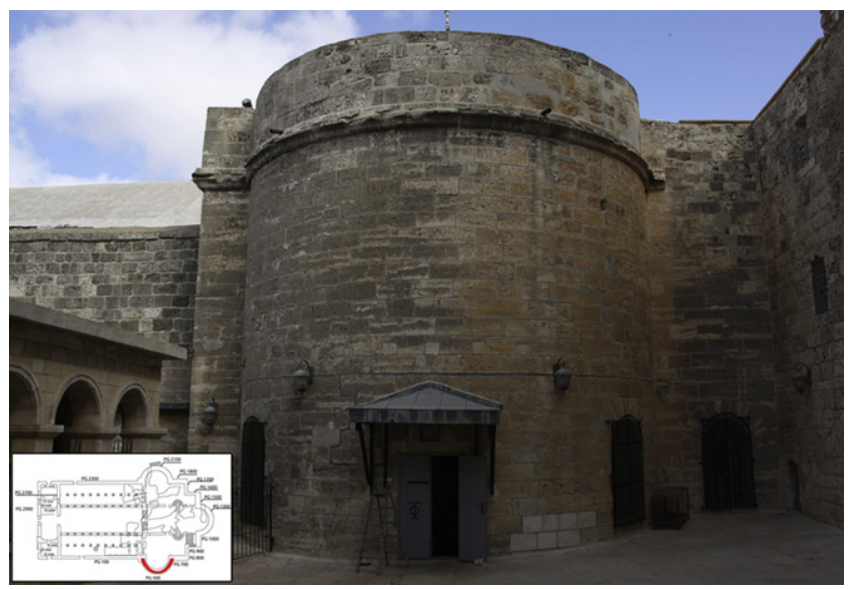

Fig. 13. Elevation 500. South apse. 


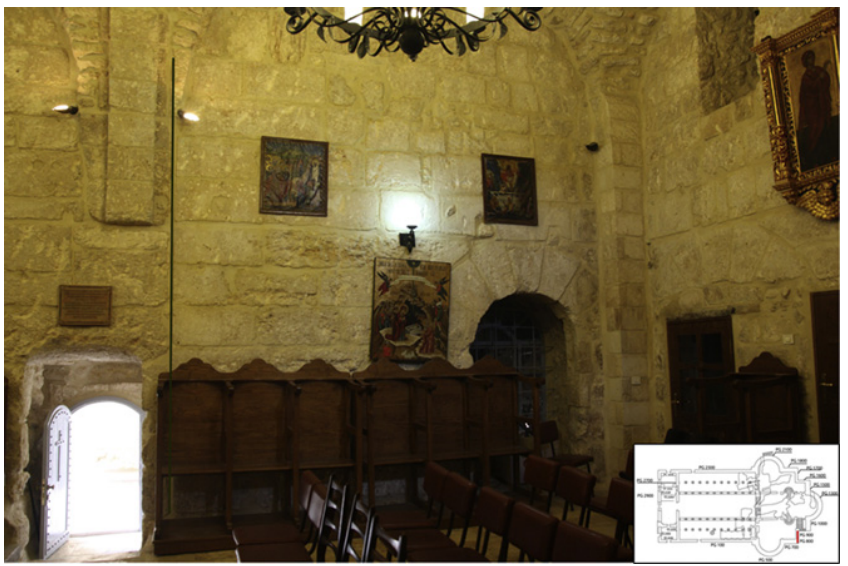

Fig. 14. Elevation 800 . The line shows the corner of the original basilica.

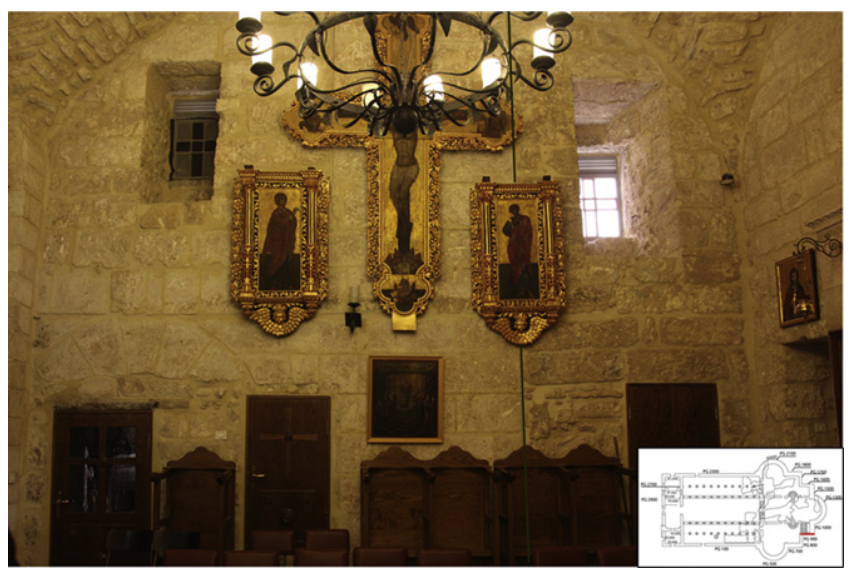

Fig. 15. Elevation 900 . The line shows the corner of the original basilica.

and the semi-pilasters joining the nave and apse, which indeed are situated at the same height above ground, construction work would have advanced contemporaneously along the whole perimeter of the basilica, creating the formworks necessary for the construction of the windows.

On the left-hand side of Elevation 200, there is a join with Elevation 300 , which constitutes the southern wall of the rear of the facade (Fig. 12). An irregular break line (shown in the photo) means

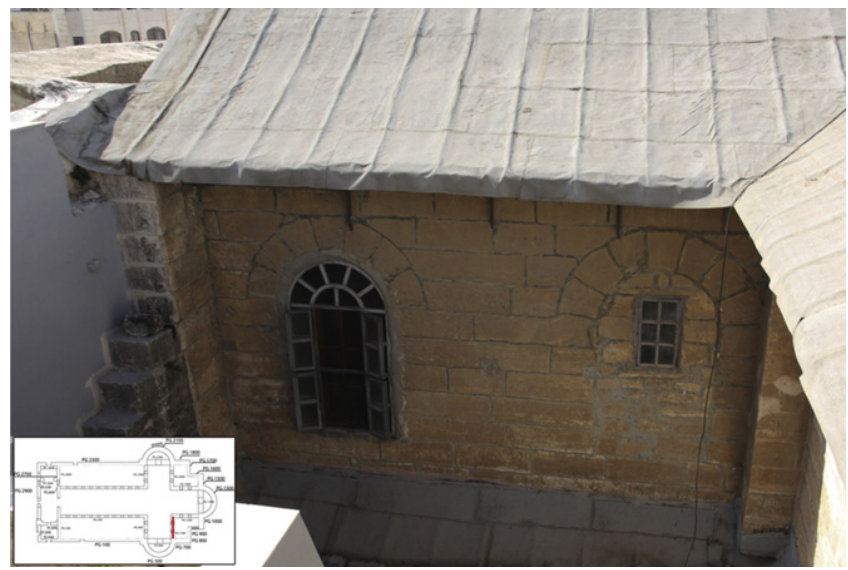

Fig. 16. Elevation 1100. Connecting wall between south transept and eastern apse.

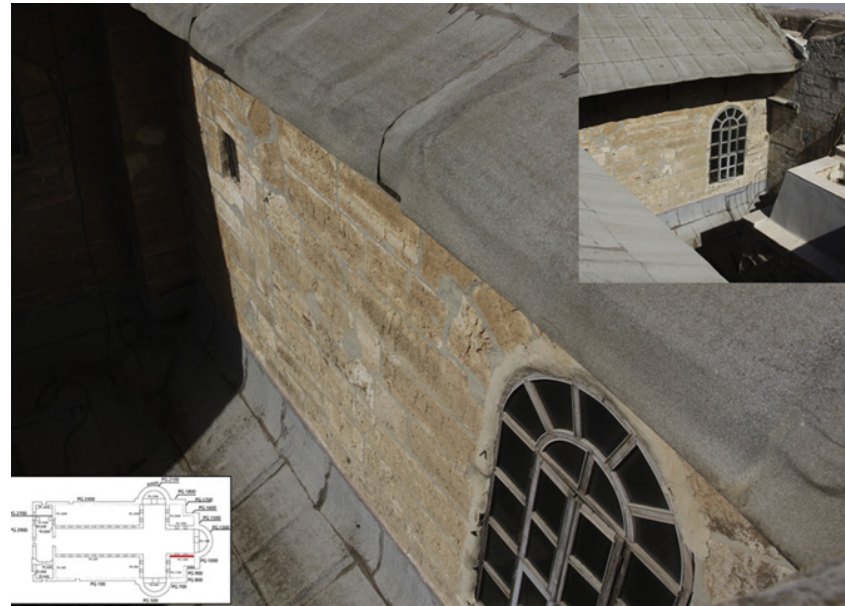

Fig. 17. Elevation 1200. Connecting wall between south transept and eastern apse.

it is not possible to know the original form of this section of walling, which on the facade functioned as a form of scenery, in other words it brought the level of the wall of the side naves into line with that of the central nave, despite the fact there is an empty space on the rear side.

Both the perimeter wall of the nave (Elevation 100) and the perimeter wall of the transept (Elevation 400) are stratigraphically connected to the wall of the south apse (Elevation 500). This is further confirmation of the fact that the nave and the body of the apses are substantially contemporaneous in their construction (Fig. 13).

In the apse elevation, at the level of the courtyard, there are three doors, with round arches. These stand on the internal side of the church, at a level around 2 metres higher than the actual ground level. This difference in height, which must have existed right from the start, requires a set of steps to reach the level of the nave. In the past, the central door must have had a sort of projecting porch roof, and indeed in that position one can still see the traces of 6 squareshaped holes cut into the wall and later filled in, and traces of the illumination system, which took advantage of the gaps between stones in the courses of masonry, expanding those gaps.

A stringcourse cornice marks the level of the floor of the terrace on the outer side of the wall, and in this same position there are a number of metal tubes emerging from the wall. They were added at a contemporary period inside cavities which perhaps already

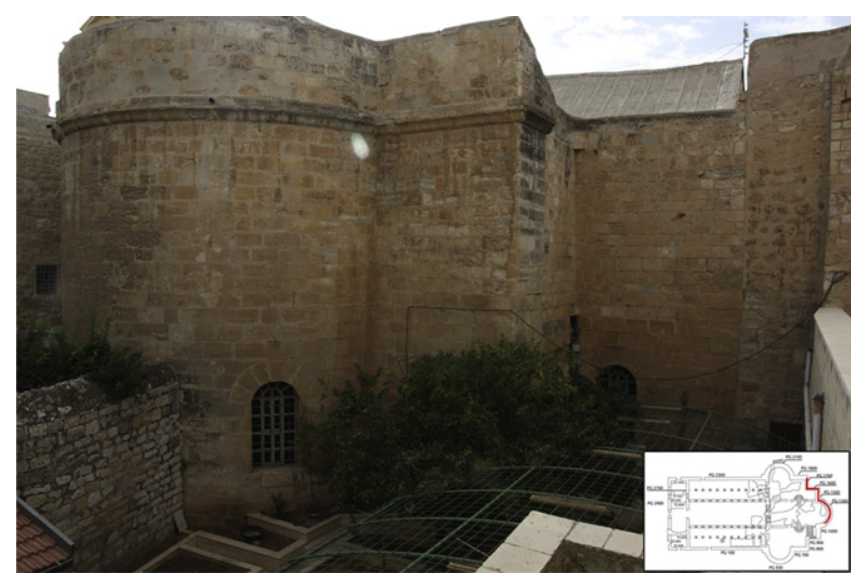

Fig. 18. Elevation 1300-1500-1600-1700. East apse and connecting walls with north apse. 


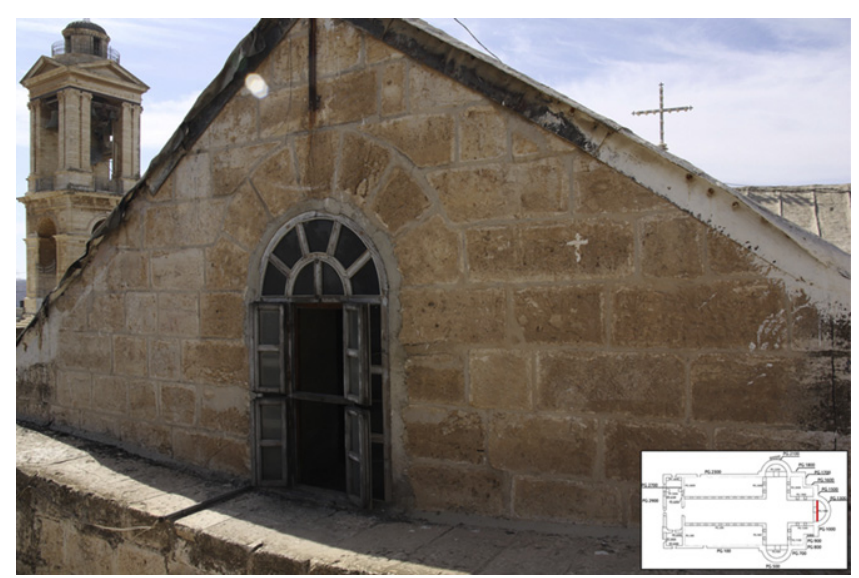

Fig. 19. Elevation 1400. Gable of central apse.

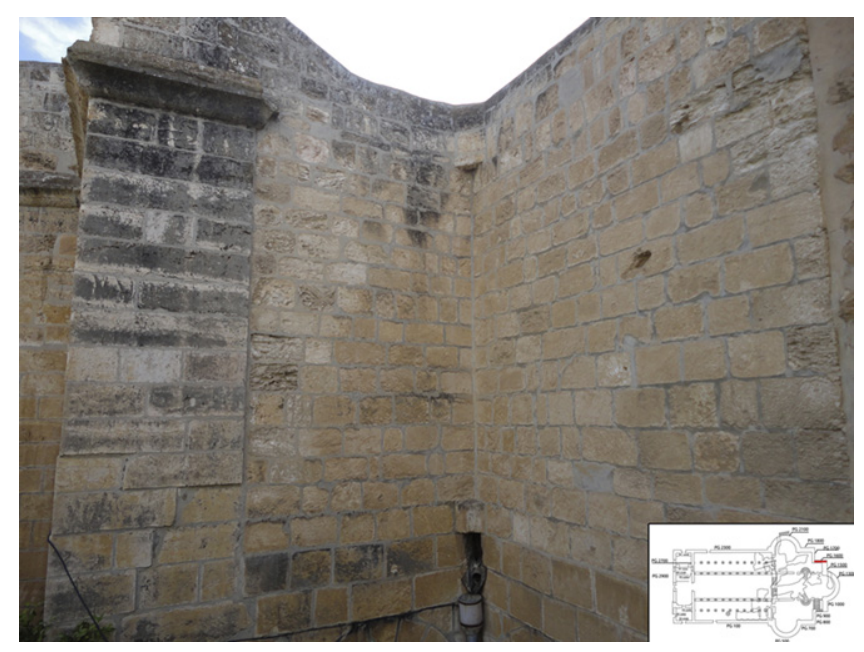

Fig. 20. Elevation 1600 .

existed, and which served to drain off rainwater that collected on the roof of the apse, which was structured in such a way as to have two main sloping points, corresponding to the two draining channels.

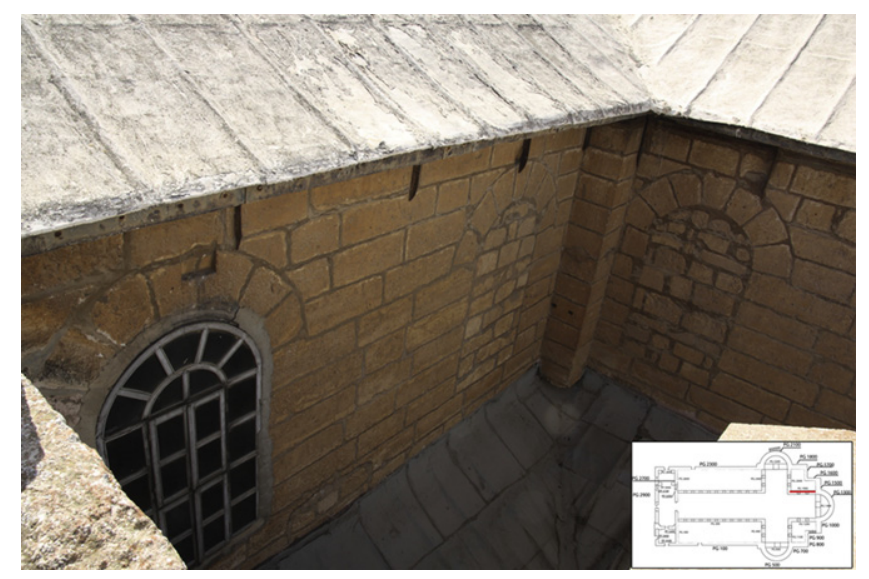

Fig. 21. Elevation 1900. Connecting wall between north transept and eastern apse.

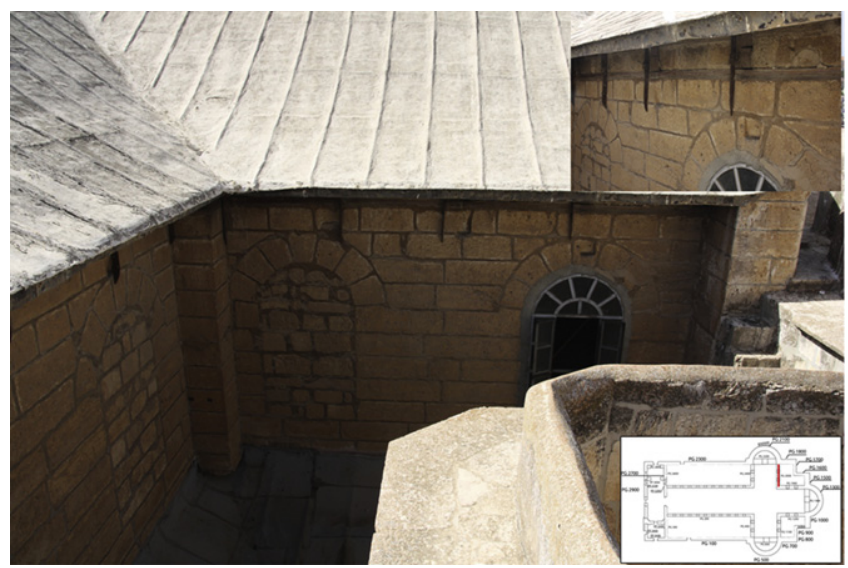

Fig. 22. Elevation 2000. Connecting wall between north transept and eastern apse.

At a point where there is a gable crowning the apse wall (Elevation 600), one finds a window similar to the previous windows, allowing direct access to the space below the roof.

The southern side of the basilica that is visible from the Greek Orthodox garden ends with the first connecting wall between the southern apse and the east apse (Elevation 700), against which abuts to the east the corner of a building constructed in the Crusader era which borders the eastern side of the complex. At the centre of the elevation, at the level of the modern-day courtyard, one finds a round-arch window, similar to the other ones seen so far, which, on the nave side, is situated a few meters from the floor level inside the basilica. The string course cornice, situated as the continuation of the cornice from the apse, does not occupy the whole width, and is limited to the portion adjacent to the apse wall, very probably

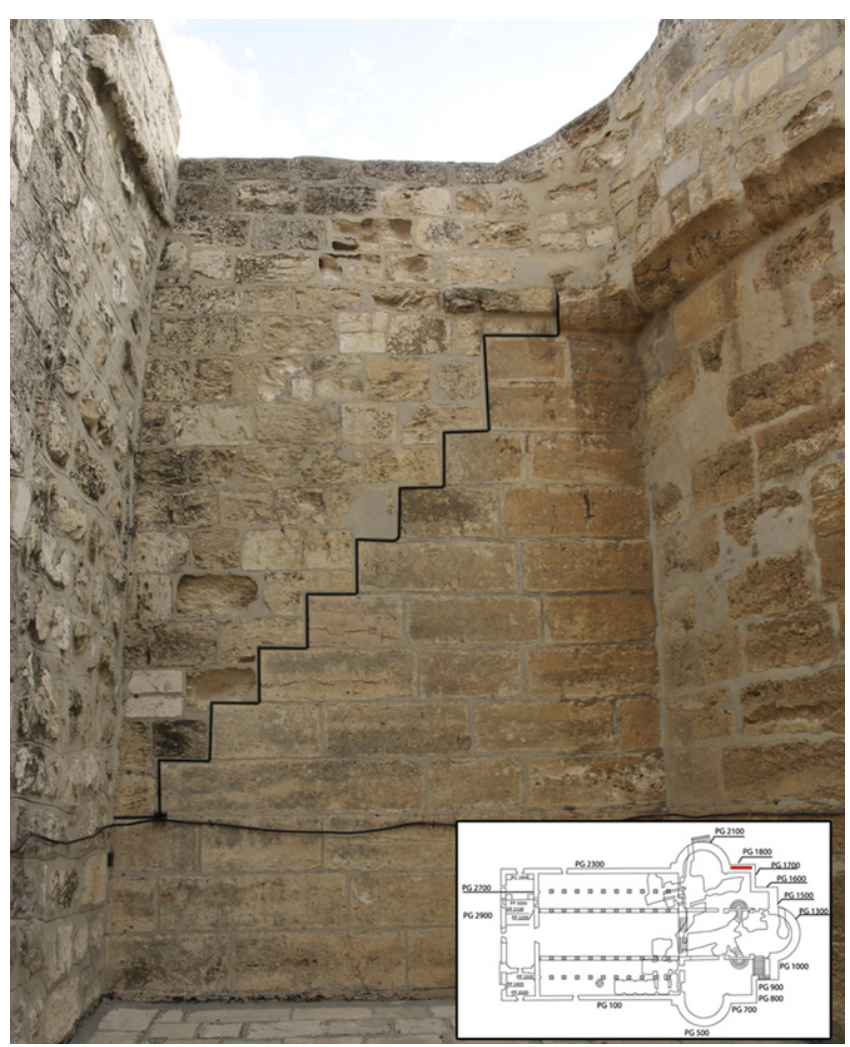

Fig. 23. Elevation 1800. The line shows the reconstructed section of wall. 

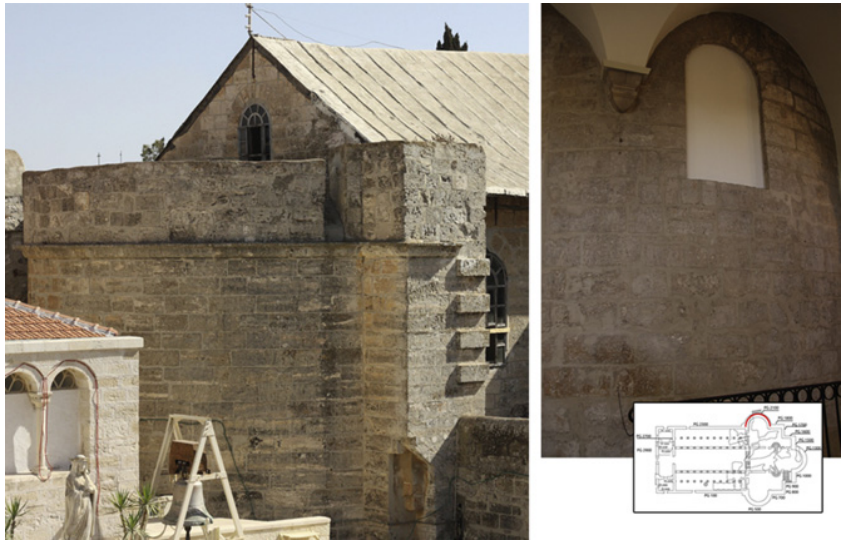

Fig. 24. Elevation 2100. Exterior view from terrace, and interior view from Church of St Catherine.

taken away and replaced by a compensatory wall elevation which is still clearly visible in the upper section of the wall (shown in the photo). As well as this reconstruction intervention, a minor fill, visible at a point where one of the illumination fittings in the outer courtyard had been fitted, could also be the result of more recent restoration work.

4.2.2.2. Eastern facade. The eastern facade of the basilica, divided into the area that is the responsibility of the Greek Orthodox Church, on the south-eastern side, and the Franciscans to the northwest, is dominated in the centre by the volume of the central apse, and it is partially covered by a building erected in the Crusader era in the south-eastern corner. The construction of this building very likely also altered the shape of the walkways created above the apses. In this case, the raised walkway between the southern apse and the eastern apse is blocked by the presence of the terrace of the aforementioned building.

The first two elevations comprising this facade of the basilica, Elevations 800 and 900, are currently situated inside the aforementioned building, and, despite being heavily reworked, they still preserve almost intact remains of the two round-arch windows already seen in the adjacent elevations (Figs. 14 and 15). Furthermore, in Elevation 900, just above the remains of the arch, a new, smaller, rectangular window was created, at an indeterminate

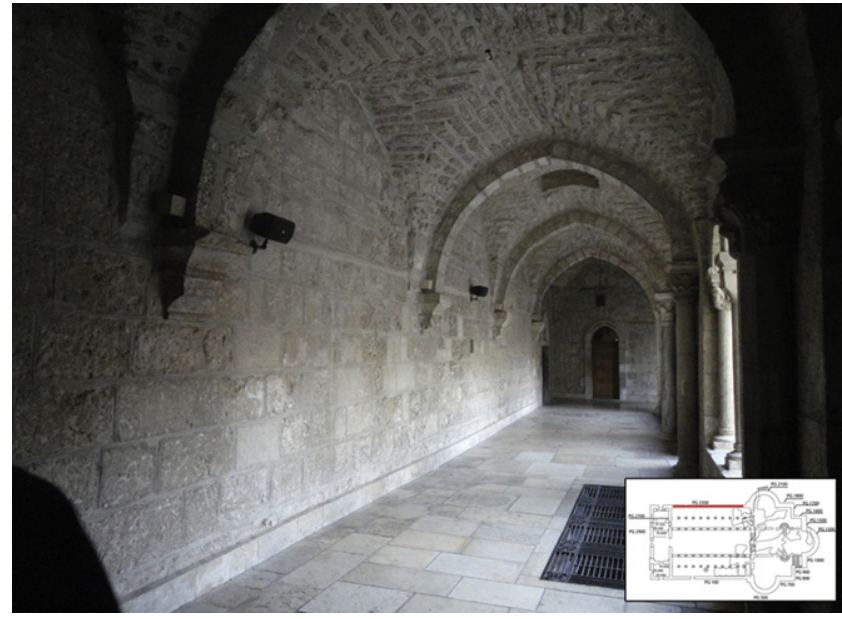

Fig. 26. Elevation 2300. Perimeter wall of northern aisle, located in Franciscan cloister.

moment in time, and the original drain for rainwater was concealed by a fake pilaster abutting the internal corner.

The two elevations situated above the roof of the lesser naves, Elevations 1100 and 1200, comprise respectively the eastern wall of the southern transept, and the connecting wall between the southern transept and the eastern apse. These are stratigraphically associated, both with each other and with the two apses which they connect (Figs. 16 and 17). The width of the two elevations is occupied by four large round-arch windows. Of these, the two situated in the point of contact between the two walls are blocked up, with two smaller windows created in the fill.

In the lower section of the outer wall of the basilica's central apse (Elevation 1300), one sees one of the three doors that, like the other apses, gave access through the apse wall (Fig. 18). In the upper section of the wall, probably rebuilt, at least in part, one sees some tubes emerging from the wall's surface, just above the stringcourse cornice marking the level of the paving of the terrace. These allowed rainwater to drain off from the terrace itself. Indeed, the paving of the terrace has two sloping points directed towards the outer drainage points, and a third slope down to the space outside the church, situated between the eastern and northern apses.
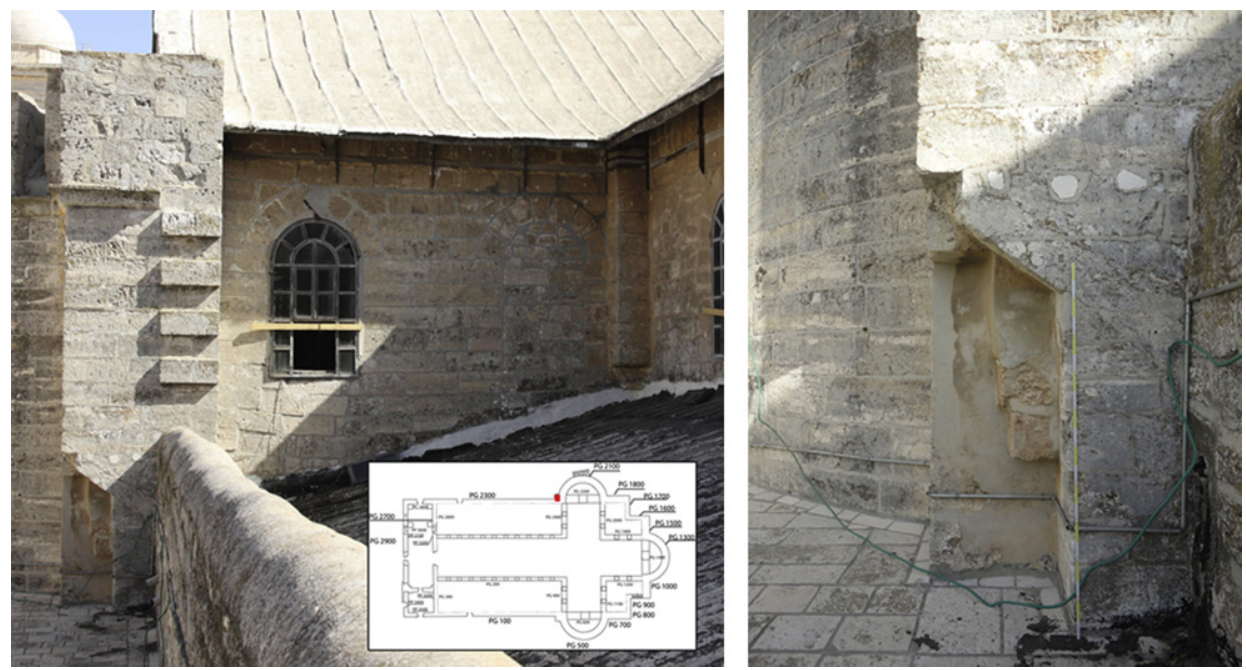

Fig. 25. Elevation 2400. Point of connection between north apse and wall of nave. 


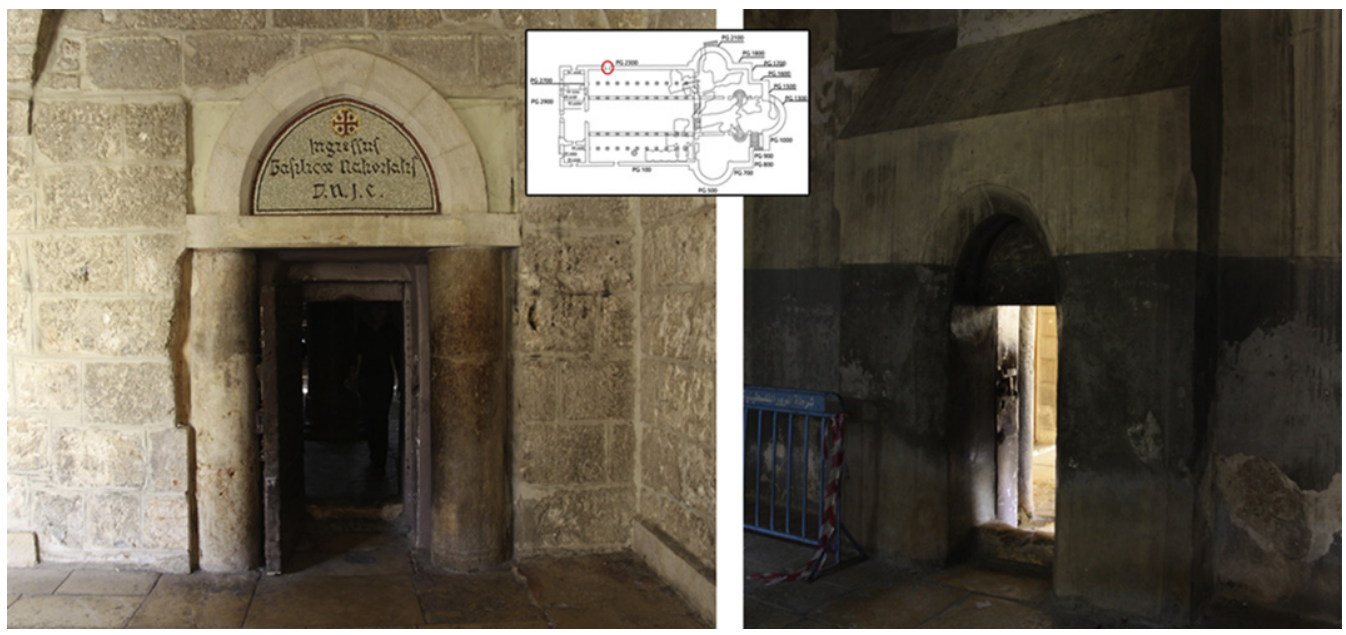

Fig. 27. Elevation 2300. Door located in western side of elevation.

The apse wall is completed by a triangular gable roof (Elevation 1400), in which there is a round-arch window allowing direct access to the space below the roof (Fig. 19). A narrow walkway, created by the original builders on the crest of the wall, enabled access between the eastern apse and the northern apse, very likely to be able to carry out maintenance work on the roof.

The connecting walls between the eastern apse and the northern apse, Elevations 1500, 1600 and 1700, do not display signs of

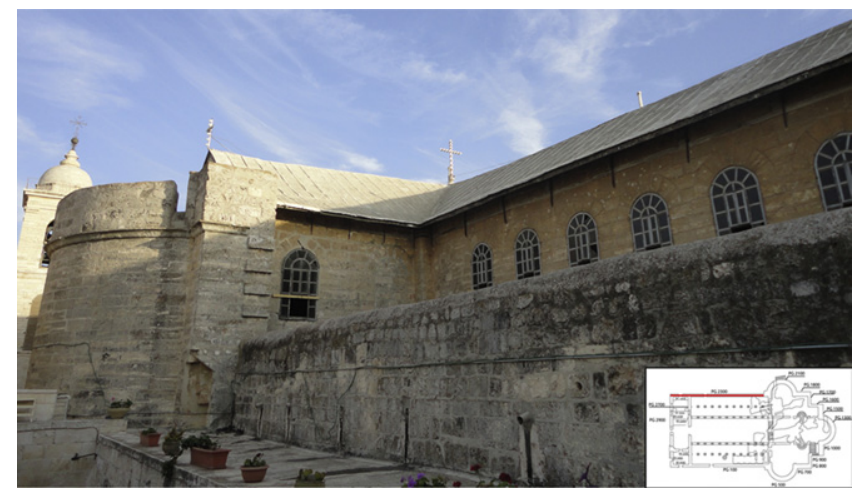

Fig. 28. Elevation 2300. Top section of wall of north aisle.

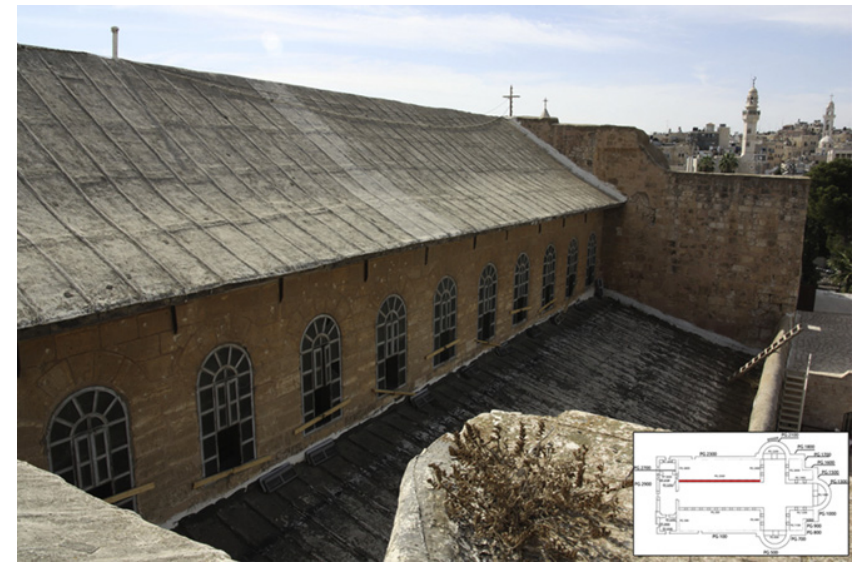

Fig. 29. Elevation 2500. Top section of wall of nave. interruption in their build. At the ground level of the courtyard, there are three doors in these walls, all topped by a round arch. In Elevation 1600 the cornice adorning the upper part of the wall was limited, ever since its origin, to the eastern half of the wall, to define a sort of pilaster, against which the remainder of the wall abuts stratigraphically. This does not denote the fact that it was built later, and only indicates a particular method of construction (Fig. 20). Indeed, at the same height as the cornice, the elevation is stratigraphically bonded with the adjacent Elevation 1700, in the form of a number of courses lain diagonally, connecting the two elevations. Similarly, a large block of stone found lower down, just above the window arches, acts as an architrave for a gutter channel for rainwater from the gullies in the roof, located in the internal space. This system is of considerable importance, insofar as it is the only extant evidence of the original system of drainage of water from the roof of the basilica.

On the right-hand side of Elevation 1700, there is an abutting wall that acts as a buttress. This was built at a later time, probably owing to a slight landslip in the direction of the natural lie of the terrain, which slopes steeply to the north. It appears that this is also shown by the fact the wall itself slants away from the perpendicular.

The two elevations situated above the roof of the lesser naves, Elevations 1900 and 2000, constitute respectively the connecting

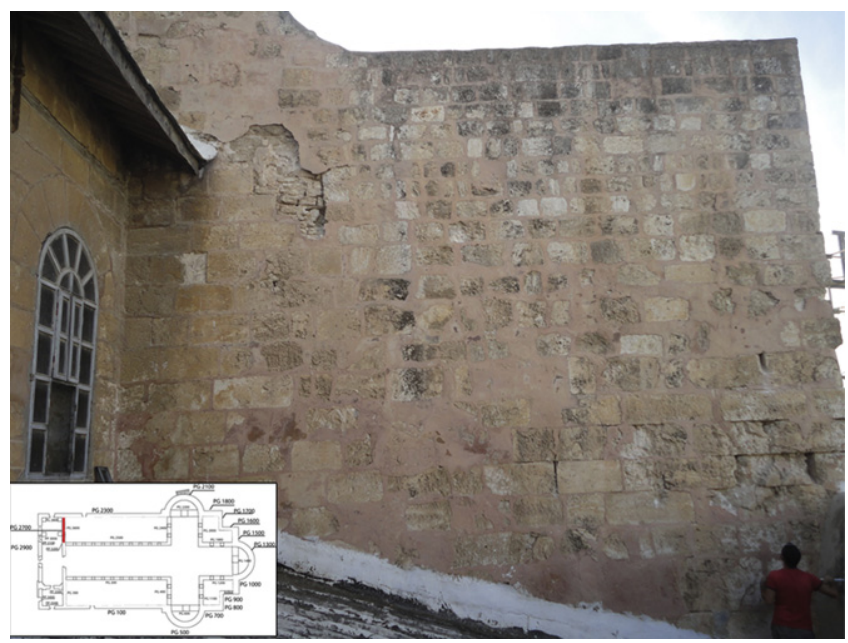

Fig. 30. Elevation 2600. Rear of façade wall. 
wall between the north transept and the eastern apse, and the eastern wall of the northern transept, which are stratigraphically connected to each other, and to the two apses which they connect (Figs. 21 and 22). The width of the two elevations is occupied by four large windows with round arches. Of these, the two situated in the point of contact between the two walls are blocked up. The keystone of the arch of the eastern window has a four-sided notch, with an inclined section, symmetrical to a similar notch situated in the arch of the northern window of Elevation 2000. Judging by their inclined section, these notches could have served to support a larger roof than the one currently in existence, which was very likely created later on (detail of Fig. 23).

4.2.2.3. Northern facade. At the northern facade of the basilica, the construction of the Church of St-Catherine, and its cloister, abutting the wall of the nave, has led to a substantial transformation of the original state of affairs, incorporating part of the northern apse, and its system of access to the caves blow, inside the new church, and creating a division on two levels of the original wall of the northern nave.

The first of the walls which are to be seen from the terrace in the Franciscan zone is Elevation 1800, the last of the connecting walls between the eastern and northern apses, stratigraphically linked to the west to the apse elevation, being partially covered to the east by the buttress constructed at a later time (Fig. 23). Also, the wall has obviously been restored on the upper left-hand side (shown in the Fig. 23), probably linked to structural damage that led to the construction of the buttress itself.
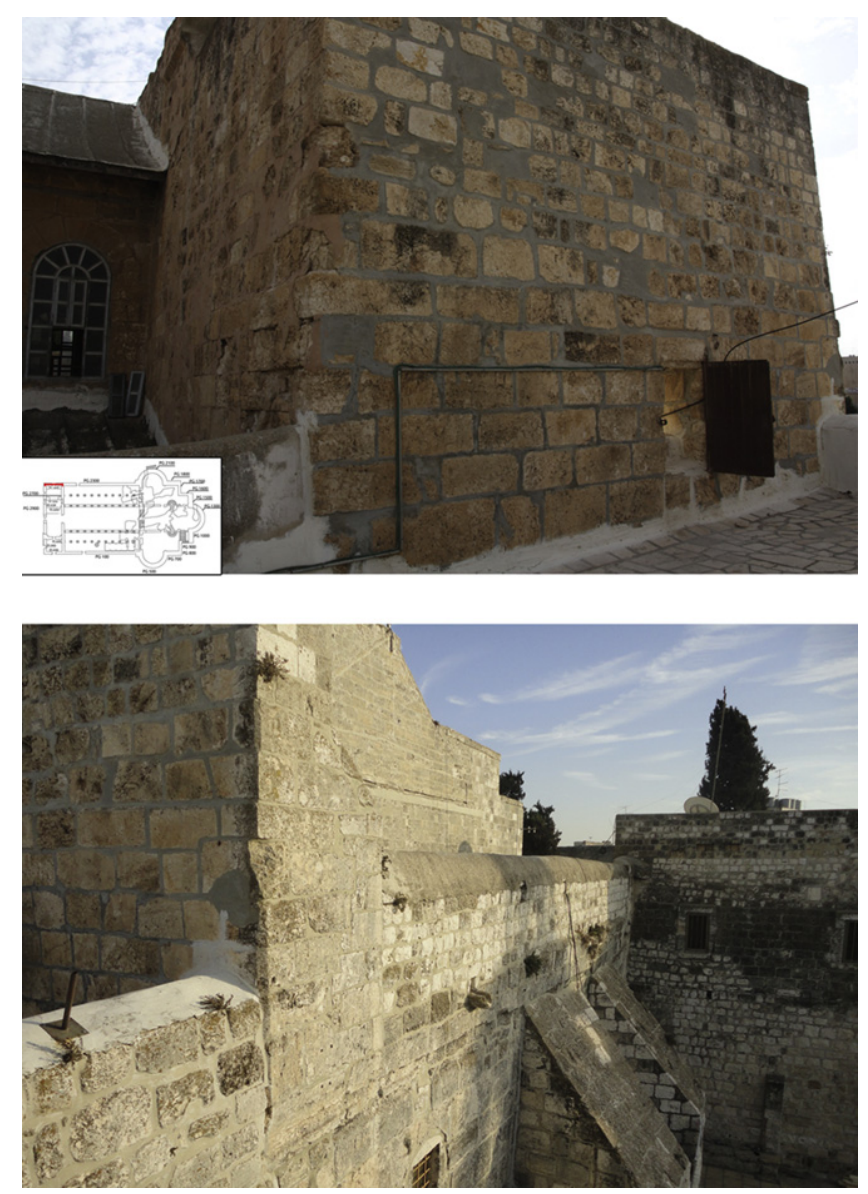

Fig. 31. Elevation 2300. Wall structure stratigraphically associated to aisle (top) and to facade of Basilica (below).
The apse elevation, Elevation 2100, is also today visible, with respect to its lower section, inside the Church of St-Catherine, and, as regards to its upper section, at the terrace level (Fig. 24). In the lower section of the elevation, in what is a demonstration of the fact that the ground levels must have been originally different on the southern facade of the basilica, there are two of the windows that illuminated the apse. These are situated a few meters off the ground, and furthermore the door still gives access to the interior of the nave. A flight of stairs also gives access to the underground chambers situated below the northern apse of the basilica. The fact that the access system and the existing basilica were contemporary is attested to by a clear, specific stratigraphic connection between the walls, and by the fact that a similar construction technique was used for the walls leading to the grotto. However, the fact that at least two of the columns of the nave seem to rest above an empty space leaves one to imagine that this grotto, like the Grotto of the Nativity, could have predated the construction of the new basilica.

In the uppermost section of the elevation, at the point where the apse wall bonds with the wall of the nave, one can observe the system of "decoration" employed by the original builders, which is partially hidden on the opposite side of the nave by the raised section of wall, which was added in the Crusader era. This is a system of four protruding stones, which jut out from the vertical elevation of the wall. They were left in that position, giving the appearance that there were plans for a new wall to be bonded with them.

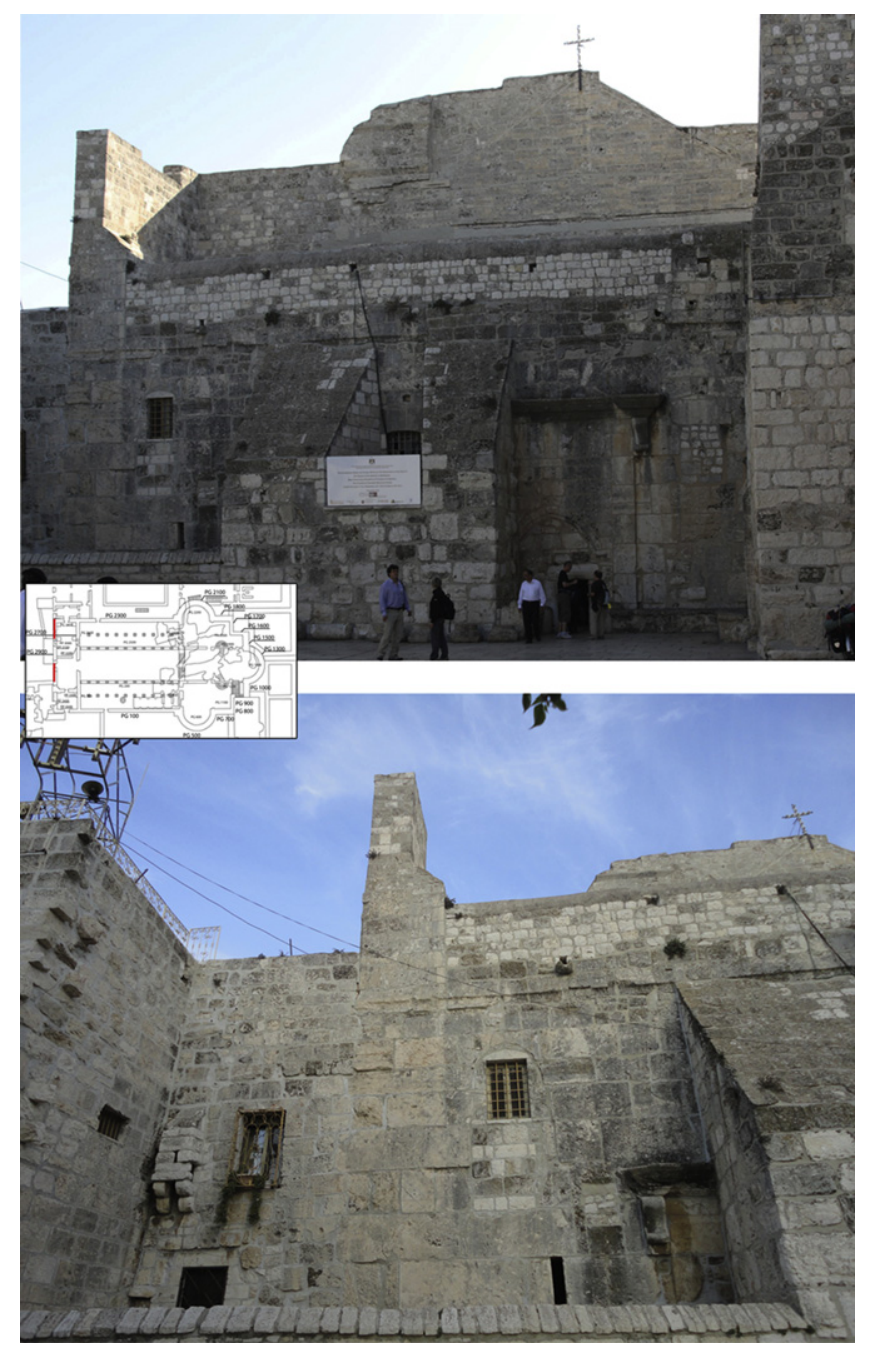

Fig. 32. Elevation 2900. Western facade of basilica. 


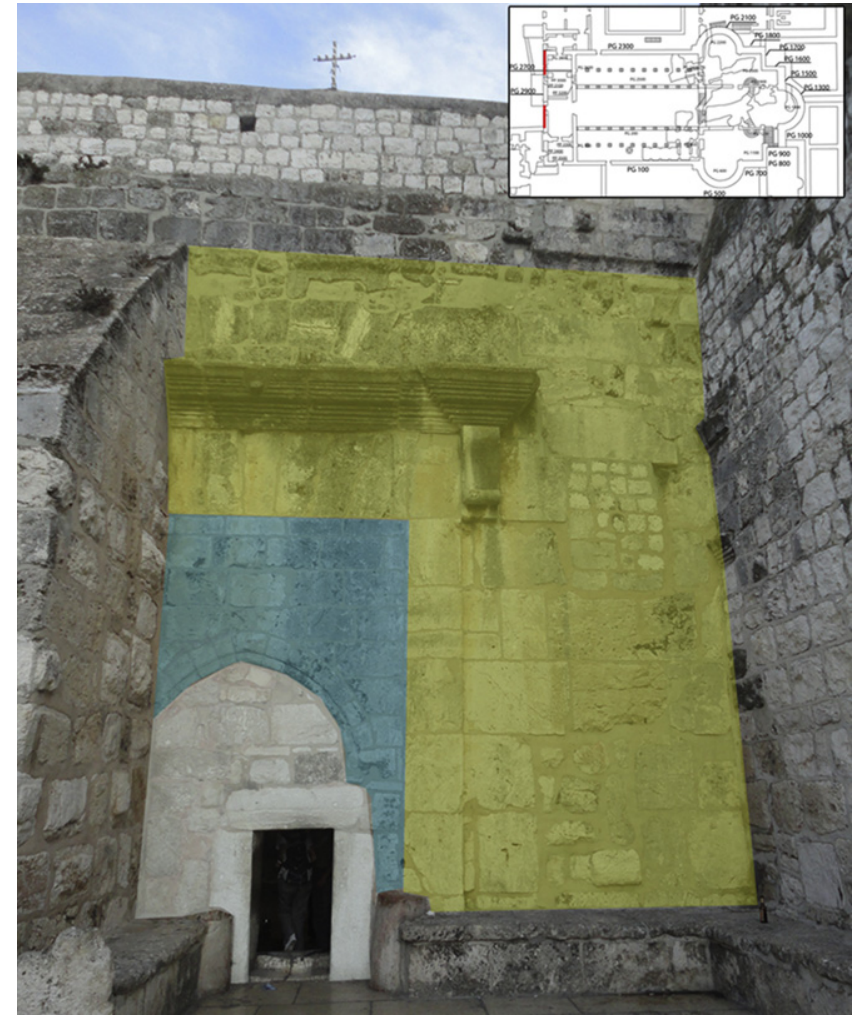

Fig. 33. Elevation 2900. Different phases of the central doorway.

However, in actual fact they merely served as a decorative device, as can also be seen on the left-hand side of the facade. Finally, a particular mode of finishing the corners, apparently connected to the wall, consists in the absence of cornerstones immediately below the aforementioned "decoration" (Fig. 25). The terrace of the northern apse, on which Elevation 2200 rises, has a single, accentuated slope from west to east, in the direction of the space outside the church, situated between the eastern and northern apses, between which the original system of raised walkways is still perfectly preserved.

Of the perimeter wall of the northern nave, Elevation 2300, there remains a section around three metres high inside the existing Franciscan cloister. Over time, there have been numerous restoration interventions on this section, as well as holes made in it to provide a footing for the ceiling vaults in the corridor of the cloister. These interventions have greatly altered its original appearance (Fig. 26). On the western side there is a small door giving direct access to the nave of the basilica. This door is framed on the outer side by two monolithic columns and by a pointed arch atop an architrave that is clearly recent. As regards the door-jambs, the one on the right could seem original, while the one on the left shows signs of having been broken and restored. On the internal side, the wall surrounding the door is framed by a thick wall, and the presence of a layer of plaster makes it impossible to define the stratigraphical relationships better, leaving a chronological attribution of the doorway still pending (Fig. 27).

The remaining portion of the wall is preserved at a point corresponding to the terrace above the corridor of the cloister. Much of this elevation is the result of a later reconstruction of the wall, similar to what we saw on the southern facade of the basilica (Fig. 28). The original portion is limited only to the two lowest courses, up to the height of the drainage tubes emerging from the wall itself, while the higher part is the result of an operation to raise the height of the wall, which probably took place in the Crusader era, as is deduced

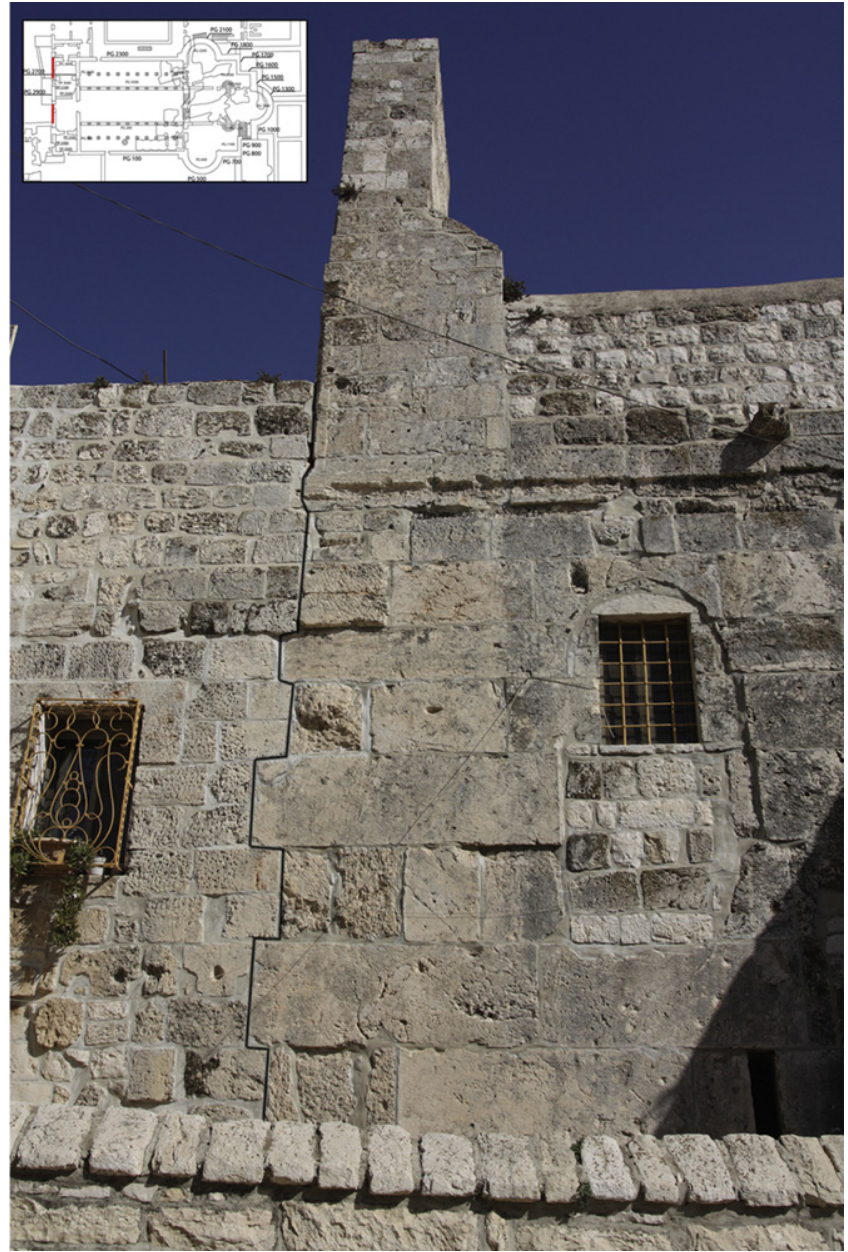

Fig. 34. Elevation 2900. Detail of northern corner.

from the stratigraphical relationships, from the construction technique, and from similar construction events found on the southern façade of the basilica.

The western wall of the north transept, Elevation 2400, a connecting wall between the walls of the nave and the north apse, features two round-arch windows. Of these, the one situated where the transept and the nave meet is blocked up, like the adjacent window in the wall of the nave. On the left-hand side of the elevation, one can see the break line in the build, which is mirrored by the break line described on the opposite side of the basilica, while on the right-hand side one sees the semi-pilaster made of stone blocks created to bond the wall with the adjacent Elevation 2500. This latter elevation constitutes the upper part of the wall of the central nave, and it has 11 round-arch windows (Fig. 29). The easternmost of these, situated where the wall meets the transept, is blocked up.

On the western side of Elevation 2300 one can see, at a point corresponding to the roof of the narthex, the perimeter wall of a quadrangular structure situated in the north corner of the basilica, whose sides are stratigraphically bonded, and thus contemporary, with the perimeter wall of the nave, by means of Elevation 2600 (Fig. 30), and with the façade wall (Fig. 31). The contemporary link is also shown by the adoption of the same construction technique. A smaller door situated in the middle of the wall gives access to the terrace above the narthex. The height of the structure was supposed to be at least as high as the top part of the roof of the central nave.

4.2.2.4. Western facade. Elevation 2900 constitutes the main facade of the basilica. Of all the elevations analyzed, this is the one 
that appears to be the result of a complex series of transformations and additions, which have revolutionized its original appearance (Fig. 32). The elegant system, which originally allowed access to the narthex, took the form of a central doorway and two smaller doors, one on each side. However, it is difficult to perceive these today, owing to a major build situated on the southern side of the basilica, which has largely obliterated the southern doorway, and a buttress built up against the façade itself, which has covered the north door and part of the central doorway. Moreover, the central doorway has, over time, seen different transforming interventions that have reduced their size. This happened initially in the Crusader era, with the addition of a wall with a pointed arch, and, later on, by further reducing the size of the access with the addition of a low architrave, creating the form of what is still today called the "Door of Humility" (Fig. 33).

In the section of the facade north of the buttress, there are the remains of the angular pilaster that defined the tower-shaped structure (see Elevations 2300, 2700 and 2800). Also remaining are the moulded cornice, above which the wall that acts as a handrail for the narthex terrace was rebuilt later on, and the remains of a round-arch window cut into the façade wall, as well as the extremity of the architrave that used to adorn the north doorway. A second window, created after the original phase, is located in the space bordered by the buttress, and a third window, now blocked up, is found alongside the central doorway.

Finally, by careful observation of the wall stratigraphy, one can also identify the traces of a very particular construction device. The large corner-stones (quoins) protruded from the vertical line of the corner itself, defining a "serrated" system similar to that found at the meeting-points between the north and south apses and the nave walls. Excluding the possibility that they were left in place to help bond a new wall, one can plausibly suggest that these stones had a purely decorative function (Fig. 34).

Elevation 2700 constitutes the facade wall of the Church, visible from the terrace situated above the narthex (Fig. 35). Once can see fairly clearly the sloping profiles of the original pitched roof of the central nave, to the sides of which the wall was later raised. The wall face also bears the traces of a roof which, after the construction of the basilica, must have been built above the narthex terrace, in relation to which there is also a series of cuts, today obliterated, which served to house a regular grid of wooden beams.

At a point corresponding to the northern pitch of the roof, one can still note the remains of the tower-shaped structure which was originally designed to decorate the north-western corner of the basilica, while to the south a small window gave access to the southern side of the pitched roof.

In periods later than the construction of the basilica, the space within the narthex was modified and subdivided, and on the southern facade, now used as a guard-room, large round arches were created, probably in the Crusader period, but these are now filled in. Of special interest is the fact that in Elevation 3200, opposite the facade elevation, traces have been found of a large doorway with an architrave, mirroring the one seen in the facade, which is now blocked in. This originally gave access to the basilica's narthex.

On the south side of the narthex, the original wall only survives to a height of a few metres, since a lowering of the vaulted ceiling obliterates the upper section. The surviving wall face still bears the marks, as for example in Elevation 3300, of the system of grooves and holes that held in place the clamps used to anchor the marble slabs which originally lined some walls of the basilica (Fig. 36). Finally, two doors were subsequently created in the south and south-western walls, allowing access to the interior parts to the south-west of the basilica, and to the Armenian garden.
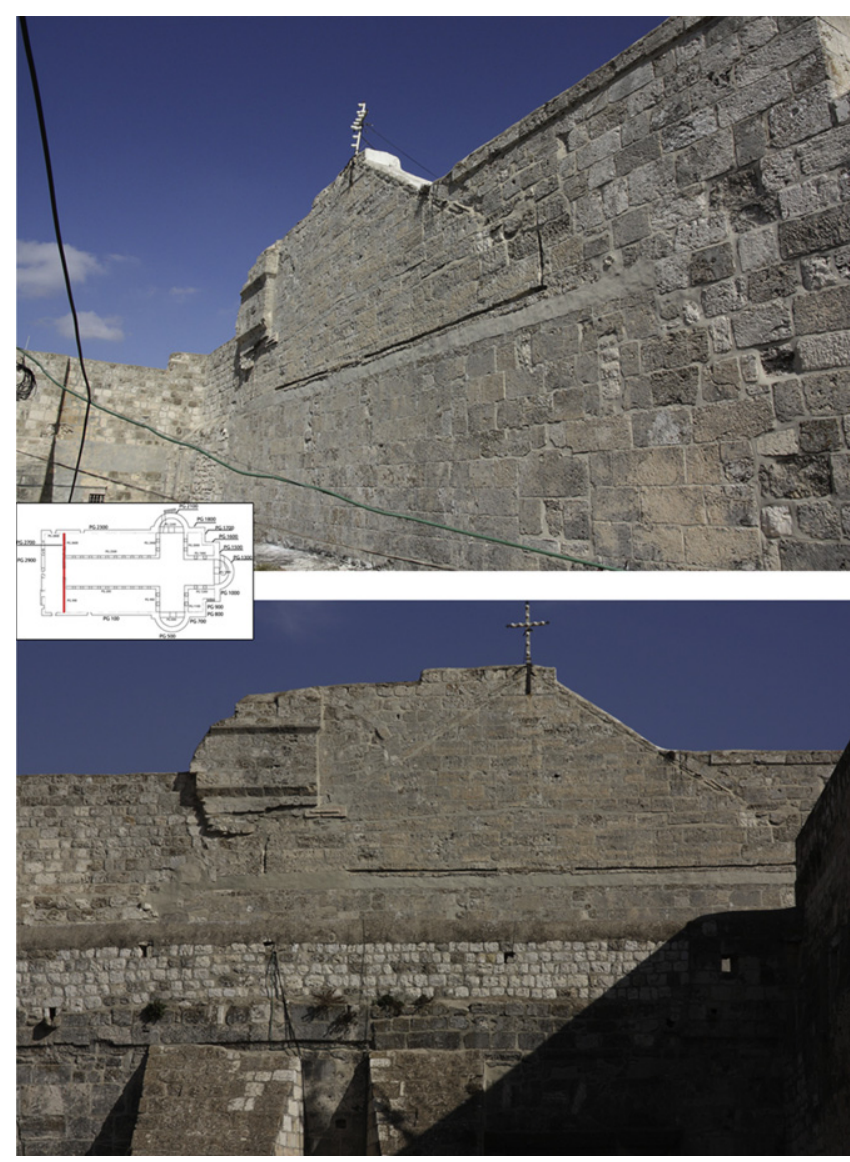

Fig. 35. Elevation 2700. Facade wall above narthex.

\subsubsection{Construction technique}

The construction technique found in all the walls attributed to the original construction phase is marked by the use of large, perfectly squared stone blocks. These were up to $1 \mathrm{~m}$ long and up to $0.4 \mathrm{~m}$ high, and were lain in horizontal, parallel courses, the height of which was fairly regular, but not always identical. The interstices between the blocks are extremely narrow, where they can be seen at all, thanks to the fact that the faces of the blocks are perfectly conjoined (Fig. 37a). Over the centuries, the application of layers of cement mortar covering the original courses means it is not possible to identify definite traces of the original bonding agent, unless this coincided with a compact, off-white mortar that is full of

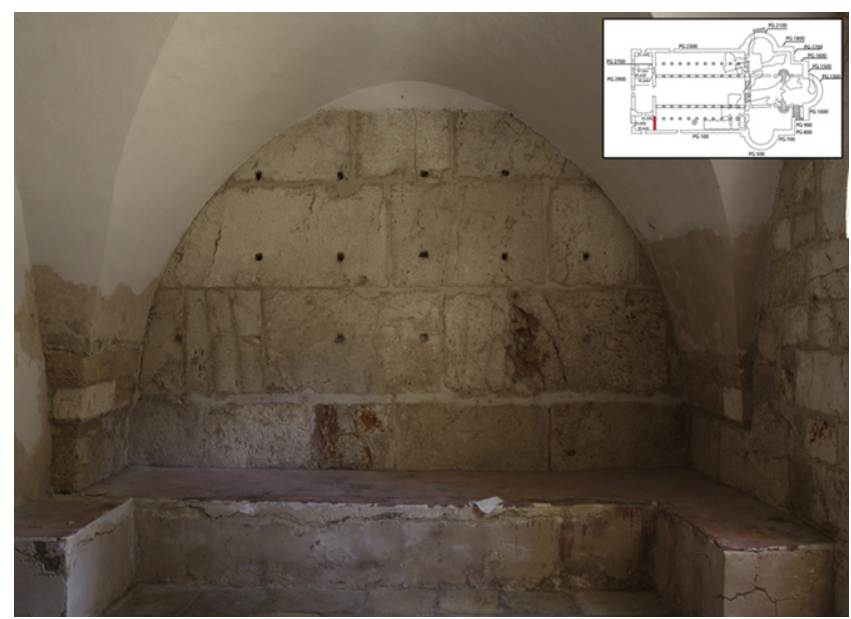

Fig. 36. Elevation 3300 . System of cavities which served to anchor the marble slabs 

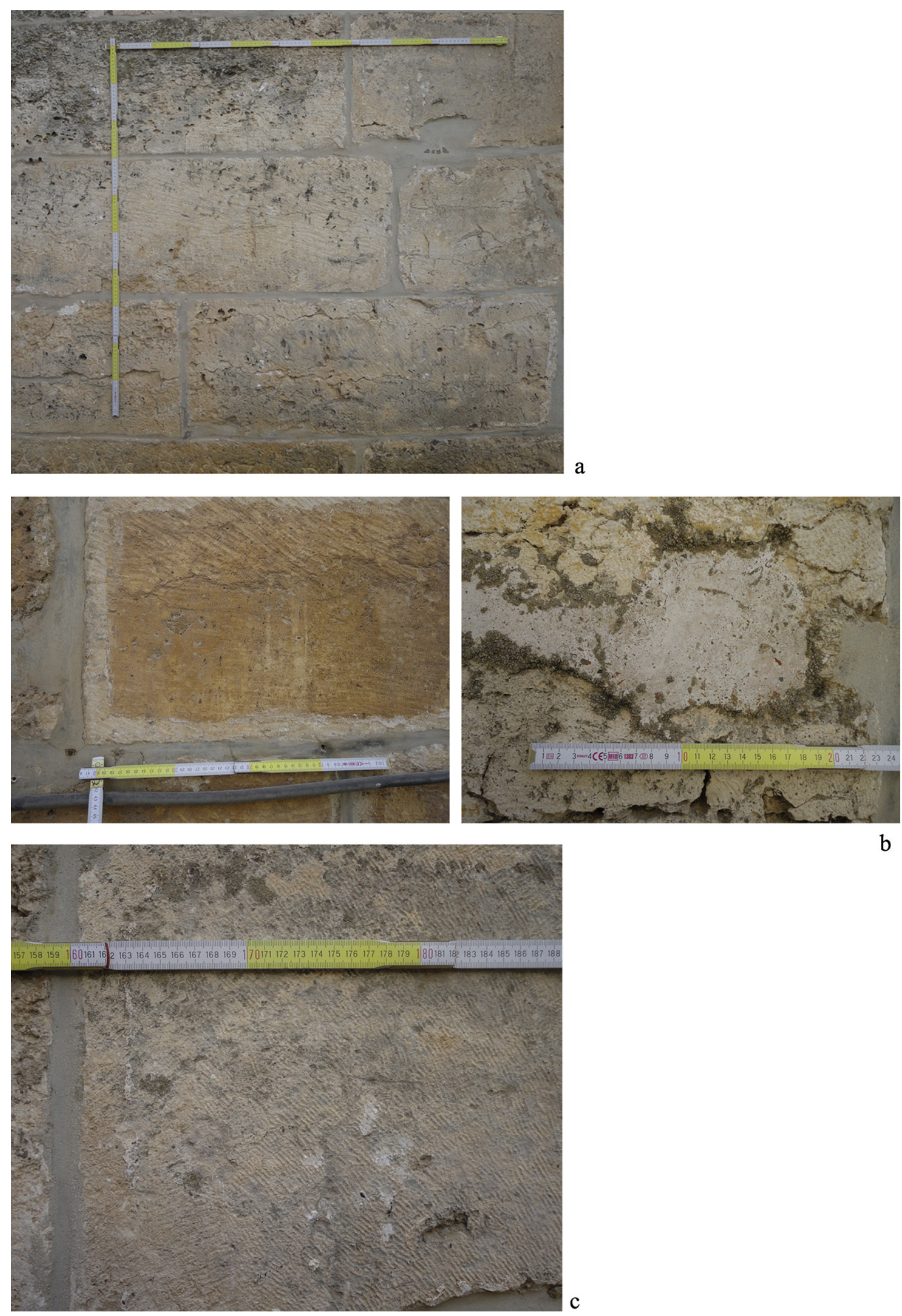

Fig. 37. a: sample of building technique; b: traces of mortar and finishing characterizing the walls of the eastern and north apses; c: traces of masons' tools. 

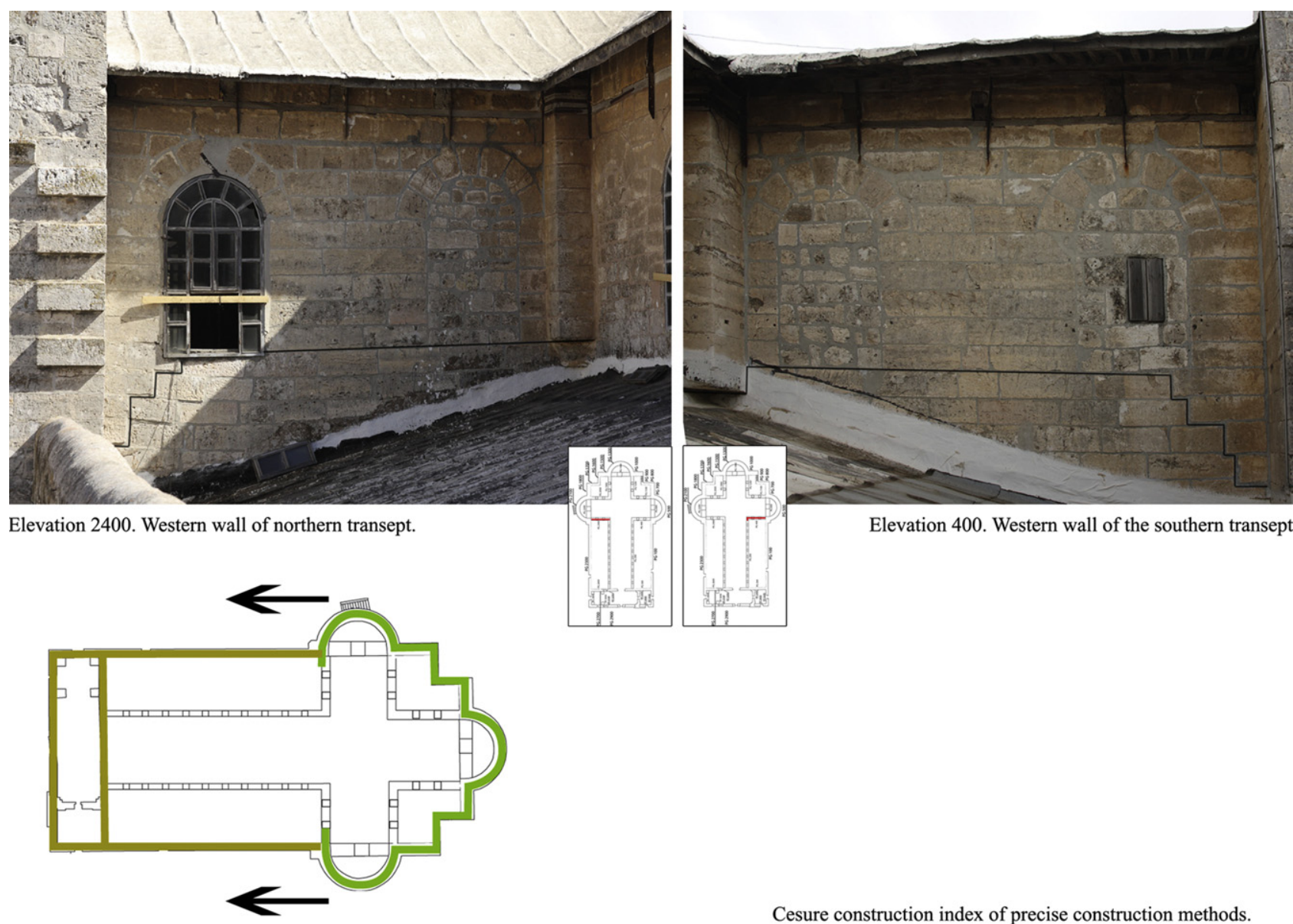

Elevation 400 . Western wall of the southern transept

Cesure construction index of precise construction methods.

Fig. 38. Evidence of interruptions in the build in the wall elevations, and construction techniques.

fragments of crushed brick or tile which also coated the edges of the individual blocks, and which is sometimes inscribed with a pointed tool (Fig. 37b), visible especially in the area of the north apse of the basilica.

The marks left by workers' tools indicate the use of a flat chisel used to dress the edges of adjacent blocks (anathyrosis). This tool was apparently $2 / 3 \mathrm{~cm}$ wide. There was also another kind of cutting tool, a serrated chisel, used to smooth the surface of the blocks (Fig. 37c). The construction technique is associated with the local stone type, Malaki, which ranges in colour from pale yellow to grey, with different levels of hardness.

\section{Conclusion - G.Bianchi}

As can be seen from reading the previous paragraph, the main finding that emerges from our research relates to the unitary nature of the construction of the basilica. The stratigraphical relationships between the various parts of the walls, from the narthex to the apses, clearly indicate that the modern-day basilica is the result of a single, unitary construction process, and that most of the architectural features visible today date, surprisingly, to that phase. In other words, the weight-bearing structures have not been altered particularly over the centuries. Accordingly, these findings are the basis for dispelling the many doubts relating, for example, to the relationship between the apse section and the nave, which some scholars still believe to relate to the Constantin-era phase, or in any case as belonging to a construction phase that is different from that of the apses (See Bacci's contribution below, with reference to the views of Vincent and Abel [5], Krautheimer [46] and most recently J. Pickett).

In some cases, this interpretation has been supported by the evidence of interruptions in the build in the wall elevations associated with the junction between the nave and the apse transept (Fig. 38). By contrast, our analysis has placed this "break" line in relation to a simple pause in construction work on the building, being contemporary with the entire project as a whole, also on the basis of analogies with evidence of the same type found in numerous other buildings, for example in central and northern Italy [72]. The presence of the same break lines, and of the other stratigraphical relationships, has, in fact, made it possible to determine the sequence of the basilica's construction. After construction of the lower section of the nave and the perimeter walls of the narthex, work continued with the erection of part of the nave itself, following by that of the narthex and the apses, before continuing, in a unified manner, in the upper zone of the whole basilica, at the height of the level of the row of windows. Given that, also for symbolic reasons, the construction of most religious buildings usually began from the presbytery, we can at present only suggest a number of hypotheses to explain the practice adopted here. These include the possibility that, by building the largest part of the basilica first, it would have been possible to reduce the length of time during which it was not possible to use the presbytery, where religious functions were conducted, and below which the Grotto of the Nativity itself stood.

As already mentioned by other scholars, and as is now confirmed by archeological analysis, access to the basilica built in this phase was via a narthex with three doors, the middle door being the largest. Originally, the narthex did not have the internal partitions 
that are visible today. These were added in the Crusader period, and the narthex was decorated with marble lining the internal walls. On the left (of the facade), above the roof, there must have been a sort of small tower, later transformed into a bell-tower [13].

A nave divided into five internal partitions, originally lit by a series of 11 windows, led to the area where the transept, choir and apses merged into a three-part area.

Bacci's article in this contribution provides a summary of the history of studies on the basis of which several scholars have attributed the total or partial reconstruction (depending on interpretations) of the original Constantinian basilica, to the period corresponding to the reign of Justinian $[5,8,13,46,47]$. In particular, on the basis of specific written documents, the date range was circumscribed by some scholars, such as Bagatti, followed later by Krautheimer, as being between 560 , the date of the absence of references to the basilica in the writings of Procopius, and 603-4, when Sophronius recorded his visit to the basilica, describing it with characteristics similar to those seen today (with particular reference to the three apses). Radiocarbon analyses of samples taken from the wooden timbers above the columns that internally divide the nave (see the contribution by Bernabei, Montadi below) have provided a date of 605 , plus or minus 50 years. This would give a chronology of between the mid-6th century and the second half of the following century. This chronology can be applied to the whole building, given that stratigraphical analysis of the walls has proved that the upper perimeter wall of the nave itself rested on this system of beams, while this same wall, in turn, was bonded to the rest of the walls of the building.

Therefore, we can say with a good margin of certainty that the start of the construction of the basilica took place in the last years of the reign of Justinian, and that, presumably, the building work continued for a number of decades thereafter, until completion of the whole building, which probably took place before the end of the 6th century.

The design features, and architectural characteristics of the basilica, as already stressed by other scholars, certainly belong to the context of the major building programmes undertaken in Justinian's reign, as already stressed by Mango [47] and Krautheimer [46]. In line with customary practice, the Empire took care of the funding of the work, while the Bishop may also have had an important role in organizing the on-site construction work, and of course the builders themselves, usually drawn from local manpower [47,73].

In the case of the Church of the Nativity, the use of large, perfectly squared blocks, accompanied by specific technical devices, devised to bond the various architectural parts (see Fichera, below), is certainly to be seen in the context of ancient Palestinian building tradition, as already argued by Mango and Krautheimer. Throughout Late Antiquity, and also for the first centuries of the early medieval period, this school of building was noted, unlike the situation in the western Mediterranean [74,75], by a continuing use of a building technique for walls that used large, perfectly dressed stone blocks, with specific tools such as, for example, those found at work on the surfaces of the basilica walls, namely the chisel and the serrated tool (see previous paragraph). The choice of the building materials themselves, such as the local Malaki stone used in the walls, as well as the cedar wood for the roof timbers in the nave (from Lebanon), are to be associated with a construction site organization that used local, highly specialized craftsmen, in the context of a geographical area that was economically particularly well-developed, both in urban and rural areas [76].

Despite the fact that, as of the Crusader period, the basilica became the centre of a major fortified complex, its original architectural features did not undergo any subsequent major structural interventions, apart from some individual episodes, such as the raising of the height of the walls of the side naves, restoration work on the roof, the creation of internal decoration, the transformation of the narthex, with the blocking up of the two side doors, and the reduction in size of the central doorway, now called the "Door of Humility".

The archeological analysis of the architecture has also enabled greater light to be shed on the relationship between the architecture of the basilica and the caves below. Indeed, it is well-known that, to the north of the Grotto of the Nativity, which stands below the presbytery area, there is a group of cavities corresponding to the Grotto of St Joseph, the Grotto of the Innocents, the cenotaph of St. Eusebius, St Jerome, St. Paula, St. Eustace and the chapel of St Jerome. Added to these, to the east there is the small grotto named after the bathing of Jesus, and a further system of grottoes to the south originally called the Grotto of the Innocents, and now generically defined as 'sepulchral' caves [13]. In most of these cavities and caves (except for the Grotto of the Nativity, which is completely lined with marble), as well as the virgin rock, also visible is part of the foundations of the basilica itself. On the basis of the findings outlined in the previous paragraph, it was noted that, both in the Grotto of the Bathing of Jesus and in the group to the south, the foundations have features that can be related to the walls of the basilica itself, and therefore they are presumably contemporary with this. Moreover, it is clear that the builders of the Justinian basilica were particularly skillful (especially in the case of the Grotto of the Bathing) in adapting the foundation walls in such a way as to not to interfere with a pre-existing situation, creating, furthermore, new accesses to the underground caves which stood below the north and east apses.

For that matter, several scholars had already highlighted the fact that, with the new basilica ordered by Justinian, the Grotto of the Nativity was probably given two new access points, corresponding to the modern-day accesses, to better control the influx of pilgrims who, in the original Constantinian basilica, were only able to view the Grotto from above, and not have direct access to it. On the basis of the findings we have made, the southern caves would seem to have been dug at the same time as the foundations themselves, and were therefore created contemporaneously with the new basilica.

One therefore has a clear picture of the complexity of the building programme embarked upon on the orders of Justinian. As well as leading to the construction of a new, large-scale basilica, this programme made the grottoes below accessible, in the framework of the creation of new, more elaborate circuits for the pilgrims. These pilgrims were offered visits not only of the Grotto of the Nativity, but also of other cavities connected to lesser events, still associated with the birth of Jesus, or else connected to important church figures. It is thus possible to suggest, in this context, that a new system of caves may have been dug, where the remains of the Innocents who were slaughtered by Herod, were kept. Later on, as of the 14th century, these were no longer venerated in this place, but in the caves to the south. While the Grotto of the Nativity could be visited by pilgrims, at least initially, by means of the access ways beneath the presbytery, the other cavities could also be reached from outside, using the entrances specially created close to the north and east apses, and along the south nave. For that matter, we know that, ever since the days of the Constantine-era basilica, the areas immediately adjacent to the basilica were especially occupied by monastic communities which, as was the case at other important places of worship, were needed to control the large-scale influx of pilgrims, above all. St Jerome had his cell in the grotto close to the basilica, and, after her arrival in Bethlehem in 386, St. Paula built her convent along the walls of the basilica. Although as of the 6th century there were ever fewer references to monastic communities abutting the basilica, it is still possible that they maintained a constant presence $[8,13]$. These new access points to the underground 
caves beside the Grotto of the Nativity, created in the period of Justinian, may have been controlled and used by these same religious communities.

\section{References}

[1] C. Alessandri, V. Mallardo, Structural assessments of the Church of the Nativity in Bethlehem, Journal of Cultural Heritage (2012), http://dx.doi.org/10.1016/j.culher.2012.10.010.

[2] C. Alessandri, et al., The roof of the Church of the Nativity in Bethlehem: Structural problems and intervention techniques, Journal of Cultural Heritage (2012), http://dx.doi.org/10.1016/j.culher.2012.10.013.

[3] N. Santopuoli, E. Concina, S. Sarmati, The conservation of the Church of the Nativity in Bethlehem and the preliminary restoration project of the decorated surfaces, Journal of Cultural Heritage (2012), http://dx.doi.org/10.1016/j.culher.2012.10.012.

[4] T. Tobler, Bethlehem in Palästina, topographisch und historisch nach Quellen und Anschau geschildert, Bern and Sankt Gallen, 1849.

[5] H. Vincent, F.M. Abel, Bethléem, le sanctuaire de la Nativité, Paris, 1914.

[6] M. De Vogüé, Les églises de la Terre Sainte, Paris, 1860.

[7] C. Enlart, Les monuments des Croisés dans le royaume de Jérusalem. Architecture religieuse et civile, Paris, 1925-1928.

[8] D. Pringle, The Churches of the Crusader Kingdom of Jerusalem. A Corpus. Vol. I: A-K, Cambridge, 1993.

[9] W. Harvey, Structural Survey of the Church of the Nativity, Bethlehem, Oxford, 1935.

[10] F. Wenzel, Ingenieurtechnische Untersuchungen an der Geburtskirche in Bethlehem, in Zeiträume: Wulf Schirmer zum 70. Geburtstag, München 2005, 261-263 (Architectura 34/1-2, 2004).

[11] W. Harvey et al., The Church of the Nativity at Bethlehem, London, 1910.

[12] R.W. Hamilton, The Church of the Nativity, Bethlehem, A Guide, Jerusalem, 1947.

[13] B. Bagatti, Gli antichi edifici sacri di Betlemme, Jerusalem, 1952.

[14] H. Stern, Les representations des conciles dans l'Église de la Nativité à Bethléem, Byzantion 11 (1936) 101-152.

[15] H. Stern, Nouvelles recherches sur les images des Conciles dans l'Église de la Nativité à Bethléem, Cah. Archeol. 3 (1948) 82-105.

[16] H. Stern, Encore les mosaïques de l'Église de la Nativité à Bethléem, Cah. Archeol. 9 (1957) 141-145.

[17] G. Kühnel, Das Ausschmückungsprogramm der Geburtsbasilika in Bethlehem. Byzanz und Abendland im Königreich Jerusalem, Boreas 10 (1987) 133-149.

[18] G. Kühnel, Wall Painting in the Latin Kingdom of Jerusalem, Berlin, 1988.

[19] J. Folda, The Art of the Crusaders in the Holy Land: 1098-1187, Cambridge-New York, 1995.

[20] T. Wright, Early Travels in Palestine, London, 1848

[21] T. Tobler, Descriptiones Terrae Sanctae ex saeculo VIII. IX. XII. et XV, Leipzig, 1874.

[22] T. Tobler, A. Molinier, Itinera Hierosolymitana et descriptiones Terrae Sanctae bellis sacris anteriora, Geneva, 1880-1885 (2 vols).

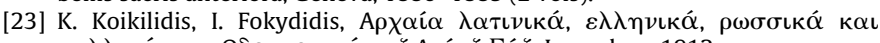

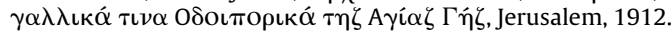

[24] D. Baldi, Enchiridion locorum sanctorum, Jerusalem, 1945.

[25] P.Geyer et al., Itineraria et alia geographica, Turnhoult, 1965.

[26] J. Wilkinson, Jerusalem Pilgrims Before the Crusaders, Jerusalem, 1977.

[27] R. Röhricht, Bibliotheca Geographica Palaestinae, Berlin, 1890.

[28] R. Röhricht, H. Meisner, Deutsche Pilgerreisen nach dem heiligen Lande, Berlin, 1880.

[29] L. Conrady, Vier rheinische Palaestina-Pilgerschriften des XIV, XV und XVI, Wiesbaden, Jahrhunderts, 1882

[30] B. De Khitrowo, Itinéraires russes en Orient, Geneva, 1889.

[31] J. Schmid, Luzerner und Innerschweizer Pilgerreisen zum Heiligen Grab in Jerusalem vom 15. bis 17, Luzern, Jahrhundert, 1957.

[32] S. De Sandoli, Itinera Hierosolymitana crucesignatorum (sæc. XII-XIII), Jerusalem, 1979-1984 (4 vols).

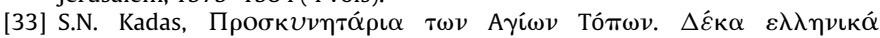
$\chi \varepsilon\llcorner\rho o ́ \gamma \rho \alpha \varphi \alpha(160 v-180 v \alpha$ u.), Thessaloniki, 1986.

[34] J. Wilkinson, J., Hill, W.F. Ryan, Jerusalem Pilgrimage, 1099-1185, London, 1988.

[35] R.B.C. Huygens, Peregrinationes tres. Saewulf, John of Würzburg, Theodericus, Corpus christianorum. Continuatio mediaevalis 139, Turnhout, 1994.

[36] R. Herz, D. Huschenbett, F. Sczesny, Fünf Palästina-Pilgerberichte aus dem 15, Jahrhundert, Wiesbaden (1998).
[37] M. Piccirillo, La Nuova Gerusalemme: artigianato palestinese al servizio dei luoghi santi, Milan, 2007.

[38] R.W.Hamilton, Excavations in the Atrium of the Church of the Nativity, QDepart Antiq Palestine 3 (1934) 1-8.

[39] G. Kühnel, Neue Feldarbeiten zur musivischen und malerischen Ausstattung der Geburts-Basilika in Bethlehem, Kunstchronik 37 (1984) 507-513.

[40] M. Halbwachs, La topographie légendaire des évangiles en Terre Sainte, Paris, 1941.

[41] E. Testa, Le grotte dei misteri giudeo-cristiane, Liber Annuus 14 (1963-1964) $65-144$.

[42] B. Bagatti, L’Église de la Circoncision, Jerusalem, 1965.

[43] J.E. Taylor, Christians and the Holy Places, Oxford, The Myth of Jewish-Christian Origins, 1993.

[44] J. Ciampini, De sacris aedificiis a Constantino Magno constructis synopsis historica, Rome, 1693.

[45] Dositheos, Patriarch of Jerusalem, 'I $\sigma \tau$ opí $\alpha \pi \varepsilon \rho \mathrm{l} \tau$. Jerusalem, 1715.

[46] R. Krautheimer, Early Christian and Byzantine Architecture, London, 1965

[47] C. Mango, Byzantine Architecture, New York, 1976.

[48] A.M. Schneider, Zur Baugeschichte der Geburtskirche in Bethlehem, Zeitschrift des Deutschen Palästina-Vereins 64 (1941) 74-91.

[49] M. Restle, Bethlehem, Reallexikon für byzantinische Kunst, München, I (1966) cols 599-612.

[50] B. Brenk, Spätantike und frühes Christentum, Frankfurt am Main-BerlinWien, 1977.

[51] E. Weigand, Die Geburtskirche von Bethlehem, Eine Untersuchung zur christlichen Antike, Leipzig, 1911.

[52] R. Kautzsch, Kapitellstudien Beiträge zu einer Geschichte des spätantiken Kapitells im Osten vom vierten bis siebente Jahrhundert, Berlin-Leipzig, 1936.

[53] R. Jaeger, Die Bronzetüren von Bethlehem, Jahrbuch des Deutschen Archäologischen Instituts 45 (1930) 91-115.

[54] Z. Jacoby, The Medieval Doors of the Church of the Nativity at Bethlehem, In: S. Salomi, (ed.), Le porte di bronzo dall'antichità al secolo XIII, Rome, 121-134, 1990.

[55] G. Le Strange, Palestine Under the Moslems. A Description of Syria and the Holy Land From A.D. 650 to 1500, London, 1890.

[56] F. Quaresmi, Historica, theologica et moralis Terrae Sanctae elucidatio, 2 vols. Antwerp 1625 (ed. Cipriano de Tarvisio. 1880-1882. Venice).

[57] M.E. Stone, Epigraphica armeniaca hierosolymitana II, Annual Armenian Linguistics 2 (1981) 72-73.

[58] M.E. Stone, Epigraphica armeniaca hierosolymitana III, Rev Etud Armen 18 (1984) 559-560.

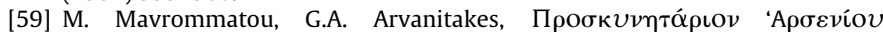
1512-1520, Alexandria, 1899.

[60] C. Couderc, Journal de voyage à Jérusalem de Louis de Rochechouart éveque de Saintes (1461), Revue de l'Orient latin 1 (1893) 168-274.

[61] K.D. Hassler, Fratris Felix Fabri Evagatorium in Terrae Sanctae, Arabiae et Egypti peregrinationem, Stuttgart, 1843-1849.

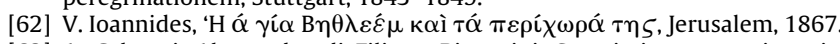

[63] A. Calamai, Alessandro di Filippo Rinuccini. Sanctissimo peregrinaggio del Sancto Sepolcro 1474, Pisa, 1993.

[64] G. Golubovich, Francesco Suriano Il trattato di Terra Santa e dell'Oriente, Milan, 1900.

[65] P.E. Castellani, Catalogo dei firmani ed altri documenti legali concernenti i Santuari della Custodia di Terra Santa. Jerusalem, 1922.

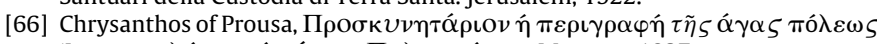

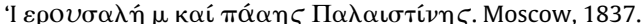

[67] L. Vincent, Bethléem, Le sanctuaire de la Nativité d'après les fouilles récentes, Rev Biblique 45 (1936-1937) 544-574 [46 (1936-1937) 93-121].

[68] E.T. Richmond, Basilica of the Nativity. Discovery of the Remains of an Earlier Church, Quarterly of the Department of Antiquities in Palestine 5 (1936) 75-81 [6 (1937) 63-72].

[69] W. Harvey, Recent Discoveries at the Church of the Nativity, Bethlehem, Archaeologia 87 (1938) 7-17.

[70] W. Harvey, The Early Basilica at Bethlehem, Palestine Exploration Quarterly Found 68 (1936) 28-33.

[71] G. Kühnel, Betlemme, In: Enciclopedia dell'Arte Medievale, Roma, 1992.

[72] T. Mannoni, A. Boato, Archeologia e storia del cantiere da costruzione, Arqueol Arquitect I (2002) 39-54.

[73] B. Brenk, Architettura e immagini del sacro nella Tarda Antichità, Spoleto, 2005.

[74] A. Cagnana, Oriente e Occidente: contatti e trasmissioni di tecnologie tra X e XII secolo, Archeologia dell'Architettura XV (2010) 197-204.

[75] B. Bianchi, Arabia e Palestina dall'impero al califfato, Firenze, 2007.

[76] C. Wickham, Framing the early middle ages. Europe and the Mediterranean, 400-800, Oxford, 2005. 